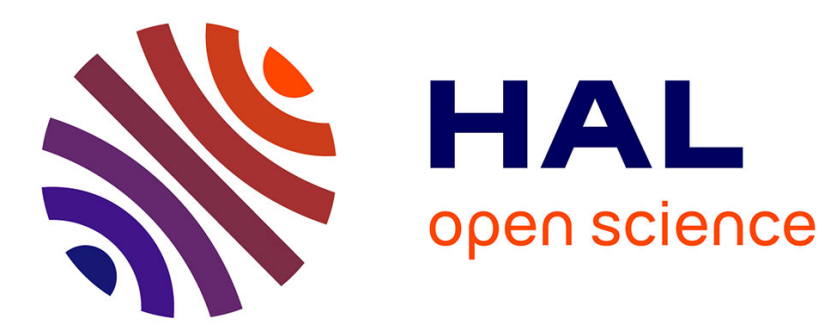

\title{
From shareholder value to CEO power: The paradox of the 1990s
}

Robert Boyer

\section{To cite this version:}

Robert Boyer. From shareholder value to CEO power: The paradox of the 1990s. 2005. halshs00590848

\section{HAL Id: halshs-00590848 \\ https://shs.hal.science/halshs-00590848}

Preprint submitted on 5 May 2011

HAL is a multi-disciplinary open access archive for the deposit and dissemination of scientific research documents, whether they are published or not. The documents may come from teaching and research institutions in France or abroad, or from public or private research centers.
L'archive ouverte pluridisciplinaire HAL, est destinée au dépôt et à la diffusion de documents scientifiques de niveau recherche, publiés ou non, émanant des établissements d'enseignement et de recherche français ou étrangers, des laboratoires publics ou privés. 
WORKING PAPER N² 2005 - 10

From Shareholder Value to CEO Power:

The Paradox of the 1990s

Robert Boyer

Codes JEL : D21, D23, G32, G34

Mots clés : Managers' control and remuneration, stockoptions, history of quoted corporations, optimal contract theory, economic and political power of managers, internet bubble 


\title{
From Shareholder Value to CEO Power: the Paradox of the 1990s*
}

\author{
Robert BOYER
}

\begin{abstract}
Why did CEOs remuneration exploded during the 90s and persisted to high levels, even after the bursting out of the Internet bubble? This article surveys the alternative explanations that have been given of this paradox mainly by various economic theories with some extension to political science, business administration, social psychology, moral philosophy, network analysis. Basically, it is argued that the diffusion of stock-options and financial market related incentives, that were supposed to discipline managers, have entitled them to convert their intrinsic power into remuneration and wealth, both at the micro and macro levels. This is the outcome of a de facto alliance of executives with financiers, who have thus exploited the long run erosion of wage earners' bargaining power. The article also discusses the possible reforms that could reduce the probability and the adverse consequences of CEOs and top-managers opportunism: reputation, business ethic, legal sanctions, public auditing of companies, or shift from a shareholder to a stakeholder conception.
\end{abstract}

\section{Introduction a Puzzling Paradox}

In the era of shareholder value, how should we explain the boom in manager's, especially CEOs' remuneration, which persisted even after the bursting of the Internet bubble? This article tries to disentangle alternative explanations of this paradox. It suggests a likely interpretation: the diffusion of stock options and financial market-related incentive mechanisms, that were supposed to discipline managers, has entiled them to express their power, not least in terms of their remuneration and wealth. This is the outcome of a de facto alliance of executives with financiers, who have exploited the long-run erosion of wage earner's bargaining power.

Why did such acute concern about managers' remuneration arise at the end of the 1990s and not before? Both corporate-related factors and the macroeconomic context seem to have played a major role in the emergence of the paradox of managers' compensation (section2). The complexity of the forces that shape the performance of corporations and the incentives that govern managers' behaviour addresses challenging questions for economic as well as managerial theories of the firm. In a sense, the search for an optimal principal/agent contract is bound to fail precisely because the objectives of the managers and

\footnotetext{
* Extrait de Competition \&Change, Vol.9. n¹, March 2005, p. 7-47.
} 
shareholders can never be totally reconciled. This article develops an unconventional interpretation of the seminal analysis by Jensen \& Meckling (1976). Given the near impossibility of convergence towards a first-best pay system for managers, there is some room for an alternative approach, taking into account the existence of a significant managerial power within the modern large corporation (section 3).

The analysis is extended to a political economy approach. During the last halfcentury the relationships between executives, employees, consumers, finance and the State have been transformed. Taking into account the shifting alliance between these stakeholders casts some light upon the issue under scrutiny: how can we explain the unprecedented boom in executive remuneration, which runs far ahead of corporate performance in terms of value creation and shareholders' wealth? The answer is simple, if not trivial: managers have used the pressures of institutional investors and diverted them for their own benefit. This gives ex post the impression of a de facto alliance of managers with institutional investors. This shift has contributed to the process that had already curbed the bargaining power of employees; furthermore the financialization of the wage/labour nexus has imposed/induced labour to accept a larger share of risk (section 4).

The bulk of the article surveys the empirical evidence from the abundant literature about managers' compensation. Numerous converging statistical analyses confirm the rather large autonomy and significant power of managers at the firm level (section 5). Similarly, it is argued that the highly specific social and macroeconomic context of the 1990s has given managers renewed power in the political arena. Even economic policy and the tax system have been redesigned according to this new distribution of power between corporations, institutional investors and wage earners (section 6).

A short conclusion summarizes the core arguments and findings. It is argued that history does not stop there. Public opinion is infuriated by the persistent rise of some chief executive officers' (CEO) remuneration in spite of poor corporate performance and sharp stock market decline. This puts two other actors at the forefront: the lawyers and more generally the judiciary. Finally, the State, even though basically pro-market and probusiness, is compelled to intervene: the Sarbanes-Oxley legislation, passed in the United States under the pressure of recurring scandals, probably opens a new epoch for corporate governance with uncertain long-term consequences.

\section{At the Origin of the Contemporary Concern about Managers' Remuneration}

The history of intellectual representation of the corporation and its various legal conceptions in a sense mirrors the actual long-term historical process of transformation of business. Each of these conceptions tries to capture a specific feature that has been dominant at some epoch. Thus the complexity of the issue of controlling and rewarding managers cannot be understood without a brief history of the factors that have shaped the present position. For simplicity's sake, a contemporary query about executive compensation may be seen as the most recent act in a drama that began more than a century and half ago.

\section{The Crisis of the Previously Successful Managerial Corporation}

The first act takes place in the last third of the nineteenth century. In most industrialized countries, and especially in the United States, family-founded and owned firms encounter limits in capturing the advantage derived from the new technologies that required more 
capital and closer links with scientific advances. A wave of mergers makes clear the merits of the joint-stock corporation as a method of mobilizing dispersed savings. This is so for the railroad industry and then the chemical industry. The invention of limited liability for shareholders plays a crucial role: individuals can diversify risk by investing in a portfolio of various traded companies. Thus the stock market and the bond market become highly liquid via the activity of buying and selling shares, quite independently of the irreversibility of productive capital and the everyday management of the company.

Consequently, there are two sources to the separation of ownership and control. On one side, family managers are replaced by salaried ones to whom the management of the firm is delegated. Incidentally, the division of labour that had taken place at the shop-floor level is also observed in the management of large companies. In a sense, managers tend to become bureaucrats in charge of taking rational decisions, informed by the advance of science, technology and management. On the other hand, individuals, as investors, enjoy the freedom to optimize the rate of return on their wealth by transacting in more and more developed financial markets in London and New York. By the way, except when scandals erupt, individual investors do not ask for close monitoring of the managers, provided they deliver a reasonable rate of return. It is the epoch of the triumph of the managerial corporation 'à la Berle \& Means': the de facto complementarity between the liquidity of saving and the specialization of management delivers an unprecedented dynamic efficiency, and therefore few criticisms are voiced by experts and public opinion on behalf of discontented shareholders. The only concern is about the risk of monopolization of product markets and concentration of capital, but these are mainly the complaints of the labour and socialist movements (Figure 1).

But the heyday of the managerial corporation does not survive into the 1970s. Act II begins when the previous favourable trends are reversed. The very diffusion of this canonical model to many activities finally triggers adverse trends. First, managers embark on excessive diversification with no clear synergy with their 'core competences', to use the term that will be proposed during the 1980s to promote the splitting of the large conglomerates. Second, this excessive diversification and the strains associated with the impact of near full employment upon labour discipline and work intensity trigger a significant productivity slowdown. Third, the oligopolistic nature of competition in product markets erodes the innovativeness of the maturing large corporation, at the very moment when newcomers in Europe and Asia challenge the American way of doing business. These strains on the managerial corporation are correlated at the macro-level with the demise of the post-World War II growth regime: the productivity slowdown generates pressures on costs that are turned into price increases due to a rather accommodating monetary policy (Aglietta 1982). The stage is ready for Act III.

\section{Value Creation and Shareholder Value as Disciplinary Devices}

The first reversal takes place in the conduct of monetary and budgetary policy. Conservative central bankers replace the Keynesian principles with a monetarist credo according to which inflation has to be curbed in order to move towards monetary and financial stability, at the possible cost of a growth slowdown due to high and unprecedented real interest rates. Since the real interest rate on bonds becomes superior to the dividend/price ratio on stocks, corporations accordingly have to adjust wages, employment and their investment decisions (Lazonick 1992). The bargaining power of wage earners is therefore eroded and this opens a new epoch for the evolution of the distributive shares between wages, profit and the revenue 


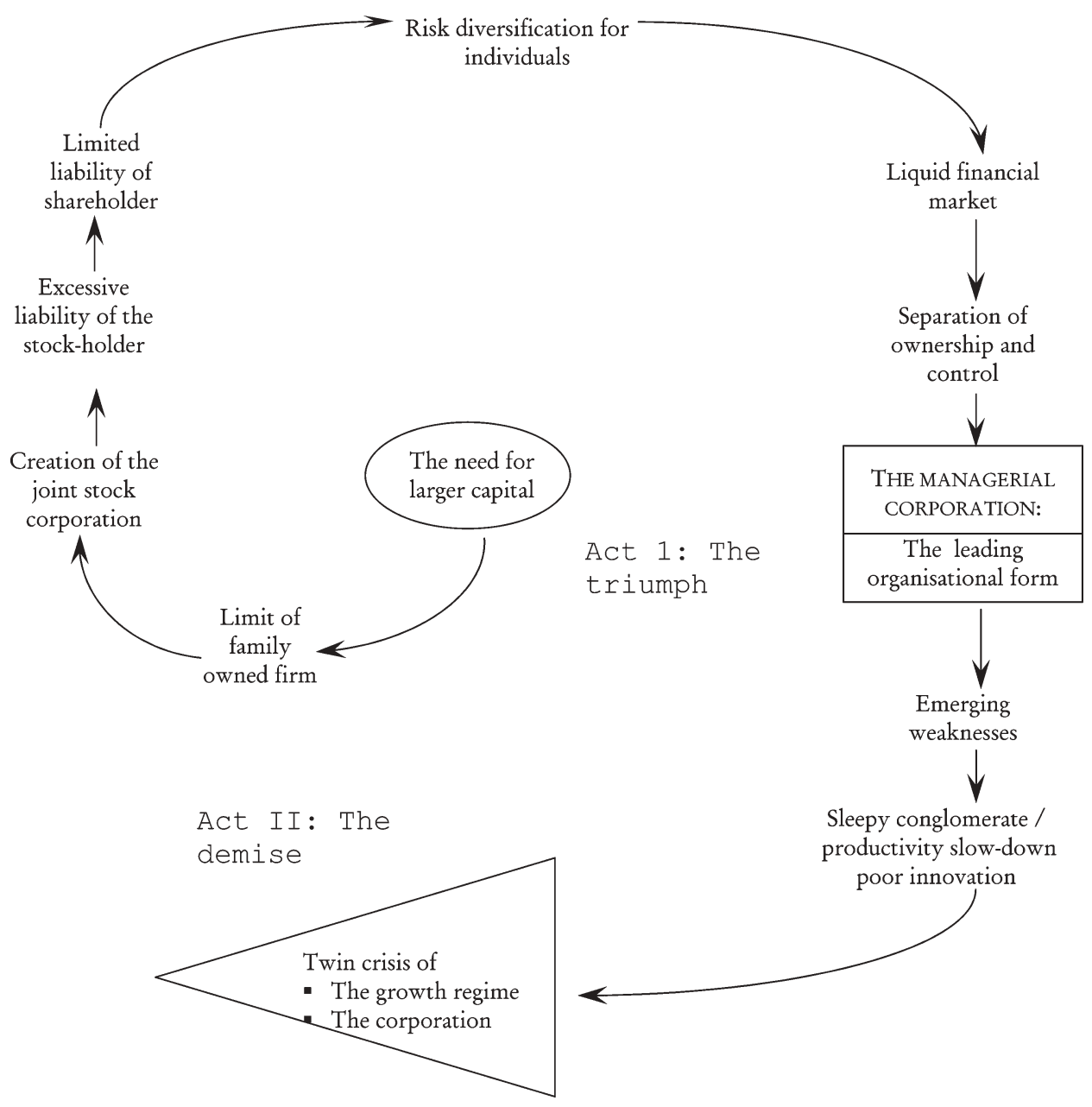

Fig. 1. Acts I and II: The emergence and the crisis of the managerial corporation.

from finance. Financial liberalization defines the second structural transformation of the 1980s and 1990s: new financial instruments are created and diffused, especially in the United States and to a minor extent in the United Kingdom. Derivatives and stock options are good examples of the success of financial innovations. Consequently, financial instruments are more and more diversified and therefore attract new customers in response to an unprecedented specialization of financial institutions and investors. A final shift, in the United States, concerns the transformation of pay-as-you-go pension systems into pension funds: the large and permanent influx of savings into financial markets improves their liquidity and depth and simultaneously increases the probability of financial bubbles (Orléan 1999). Furthermore, the concentration of the management of these savings brings a counter-tendency to the extreme dispersion of ownership: some pension funds may use not only exit (selling the shares of a badly managed corporation) but also voice (by stipulating conditions for approval of board decisions). 


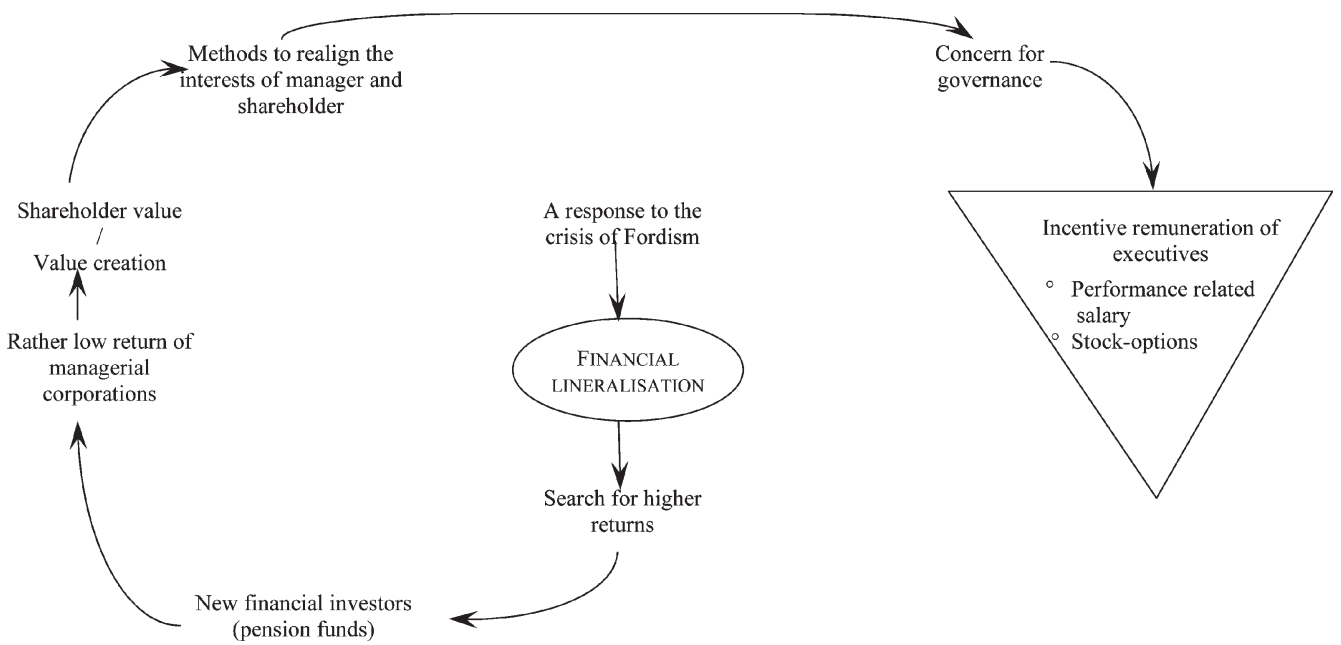

Fig. 2. Act III: disciplining the managers by shareholder value.

It is the epoch of value creation, and then shareholder value (Figure 2). In this context, the divergence of the interests of managers and owners emerges as a crucial issue. Why not try to align the strategy of top managers with the objectives of stock market value maximization on behalf of shareholders? The use of stock options is therefore widely diffused, not only to the traditional corporation operating in a mature industry but also to start-ups in the information and communications technology industry. In the former (traditional) industries, stock options are conceived as an incentive to good management and shift the strategy of CEOs from extreme diversification to concentration on their core business, and economizing on the use of capital. In the latter industries, a large proportion of personnel receive a modest wage but a significant number of stock options that can be cashed if or when the expected profits materialize. Incidentally, this reduces production costs and increases profits, since US accounting principles in the 1990s did not require stock options to be expensed in the income statement. The search for radical innovations and stock options as a form of remuneration are closely associated in the vision of the 'new economy'.

Stock options are therefore central to American business in the 1990s: they are supposed to control the managers of mature corporations and reward the professionals and managers of the sunrise sectors. Act III seemed to promise a happy ending, but such was not the case.

\section{Financial Bubble and Infectious Greed: Executive Compensation under Scrutiny}

In fact the very optimistic views about higher and higher rates of return on equities drove the boom of the mid-1990s in American stock markets. What was supposed to be a rational method of generating value and wealth has become 'a casino economy' whereby everybody tries to get rich as quickly as possible, with little concern for the long-run viability of their strategy. The implicit rate of return of most of the start-ups of the new economy was implausible but nevertheless attracted investment from well established investment banks and institutions. The public were convinced by the financial and popular press that the boom in 
the stock markets was not a bubble but evidence of an unprecedented area for investment featuring totally new economic regularities. This was an illusion, since the divorce between the actual and the expected rate of return was bound to be recognized and hence reduced, if not by a progressive reappraisal, then by a brusque downturn in the financial markets. This took place in March 2001, when the Internet bubble burst, generating an impressive series of bankruptcies: in a sense, the trajectory of Enron is typical of these new relations between corporate governance and financial markets (Figure 3).

In this context, the divorce between the supposedly rational goals of incentive pay and the effective use of financial, performance-related compensation is made clear by the multiplication of financial scandals and some spectacular bankruptcies. In retrospect, the surge of stock options appears as a method of fast wealth accumulation by top executives rather than a method of rewarding the quality of their management. The previous methods of controlling and rewarding managers are therefore under public scrutiny. Should this come as a surprise to the proponents of the indexation of top managers' compensation to shareholder value?

\section{A Major Challenge to Economic Theory}

Actually this issue is not so new. Since Berle \& Means, economists have deployed two contrasting strategies. The first takes into account the transformation of the joint-stock corporation and finally adopts the stakeholder conception, with no primacy of shareholders' interests. A second considers that the discrepancy between the optimal profit-maximizing strategy and the actual strategies of managers should as far as possible be removed, in order to restore the primacy of shareholders. In periods of patient capital and a leading role for the banks in financial intermediation the first conception may prosper. When finance is liberalized, many new financial instruments are created and diffused around the world, and when professional investors manage a large proportion of savings - especially pension funds - the issue of control and reward of CEOs became central and triggered a boom in academic research (Murphy 1999).

\section{Back to Michael Jensen and William Meckling's Seminal Article}

Within the patrimonial conception of the joint-stock corporation the problem is simple: the top executives are the agents of the shareholders, since they are hired by them in order to defend and promote their interests, namely their income and wealth. Generally speaking, principal/agent relations were already being used in the Roman empire within the rural economy, but the innovation of the manager/shareholder principal/agent relation is to mobilize specific economic incentives. What type of contract, including pay systems, dismissal conditions and fringe benefits, would realign the objectives of the CEOs with the interests of shareholders?

The literature offers a hint: in order to limit the distortion of CEO decisions in such a way as to benefit the CEO but reduce the value of the firm, a proportion of the capital should be given to the CEO in order to fill the gap between the patrimonial firm run by the owner and a joint-stock corporation under the supervision of a manager (Jensen \& Meckling 1976: 221). This result has frequently been interpreted somewhat optimistically: adequate incentive mechanisms (profit sharing, stock options, linking CEO compensation to a performance index) could overcome the discrepancy between a first-best solution 
From 'GOOD'

GOVERNANCE TO

INFECTIOUS GREED
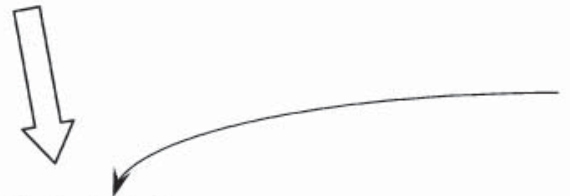

Creative accounting



delivering the

expected ROE

Collusion between

managers, auditors and

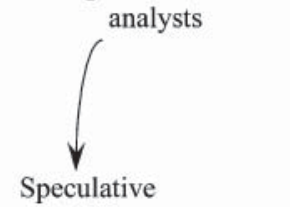

bubble
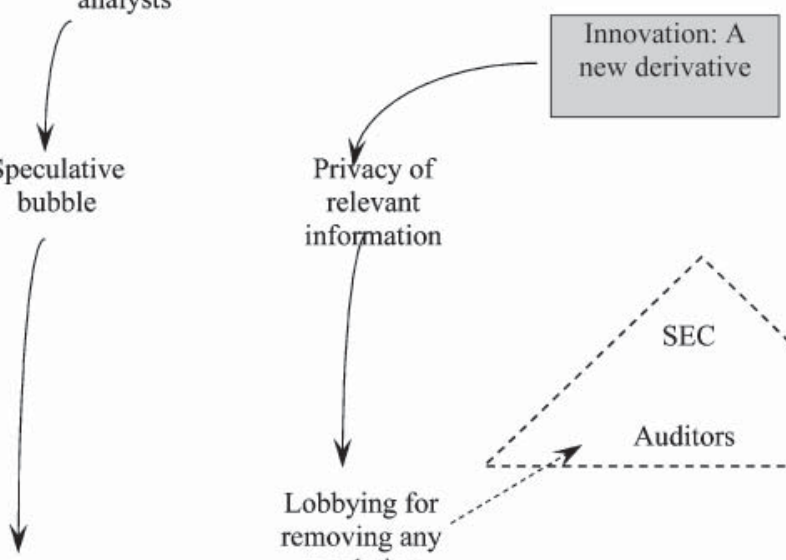

relevant
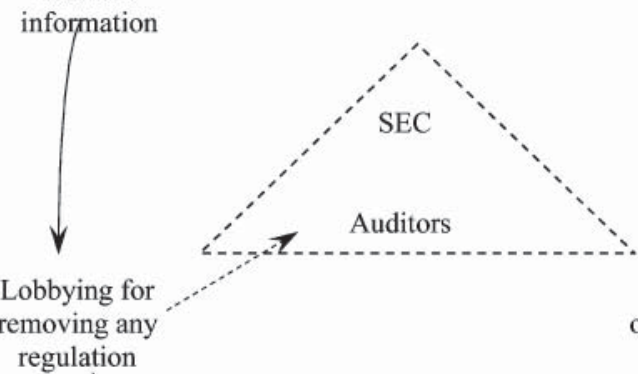

removing any

regulation
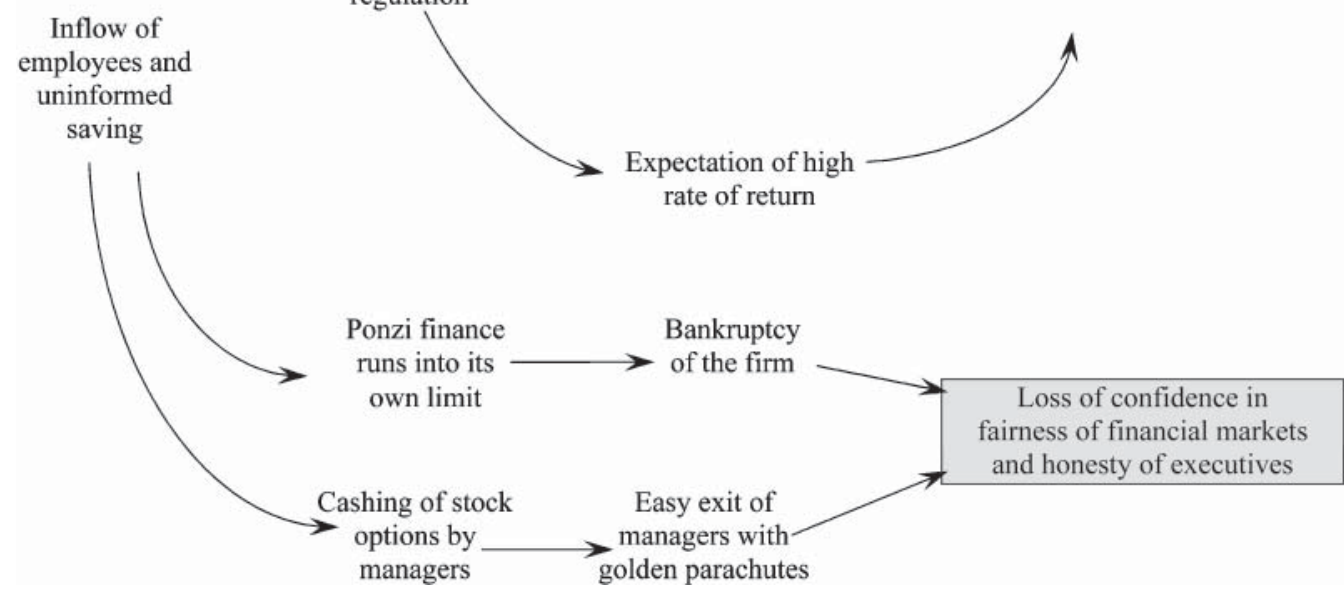

Attractiveness

of new instruments

Fig. 3. How an alleged virtuous circle turns into a vicious spiral: the Enron story.

and organization, i.e. profit maximization, and the actual decisions of managers that may distort the strategy of the firm in favour of their own interests.

A closer look at the argument shows that the cost of agency cannot be reduced to zero, because the manager has to be compensated at the expense of shareholders, unless they are given all the capital and thus become an entrepreneur without shareholders. From a purely theoretical point of view, the dichotomy between management and ownership cannot be 
overcome. Whatever the pure economic and financial incentive mechanism, there is a cost of agency associated with the joint-stock corporation. A second wave of the literature has progressively recognized the limits of these incentives. For instance, Michael Jensen and Kevin Murphy (1990) are surprised by the low sensitivity of CEO compensation with respect to shareholder wealth (approximately $\$ 3$ for each $\$ 1,000$ change in stock market value). They hypothesize that public and private political forces explain this departure from what theory would suggest. This probably explains why other mechanisms have been proposed: the strength of a corporate culture may reduce the opportunism of the executives, or a form of business ethic may play the same role. But this overestimates the degree of conformity to social norms and their effectiveness, at odds with the principle of individualism that is at the centre of modern societies. This is the reason why alternative methods of dealing with the agency problem have been proposed and, indeed, implemented.

\section{A Whole Spectrum of Incentives and Constraints}

Many CEO pay systems coexist and deliver different outcomes in terms of free cash flow, investment, diversification, risk, innovation policy and the choice between internal growth and expansion via merger and acquisition. A priori, a compensation scheme could be tailored to any precise objective articulated by the board that would transmit the will of shareholders (and other stakeholders if they are represented). Within the conventional patrimonial conception of the corporation, many devices have been proposed in order to control and reward managers (Table 1).

The value of the stock of the corporation is only one possible reference index, since $a$ bonus payment can be indexed to profits, measured according to various definitions. If financial markets are imperfect, inefficient, and if stochastic shocks affect the firm's results and its stock market value, then profit-related pay systems and stock options are far from equivalent. Furthermore, stock options are different from the attribution of stock to the managers. A basic divergence relates to accounting rules: until recently, stock options were not taken into account as costs, whereas a profit-sharing mechanism would explicitly affect the financial situation of the corporation. The various components of CEO compensation wage, bonus, stock options, fees for sitting on boards, special credit terms, severance payment, contribution to retirement - do not attract the same rate of tax. Thus, indirectly, government may indirectly influence the form of CEO compensation.

Incentive pay is not the only mechanism: shareholders' access to information about CEO remuneration may trigger their demands for control of those payments, on top of the activities of any remuneration committee. Simple transparency may have a disciplinary role when CEO compensation explodes at a time when their corporation is near bankruptcy. But such a mechanism can affect only major discrepancies between executive compensation and the firm's performance, it does not deliver the fine tuning that would be required for good governance on an everyday basis. Another avenue explores the role of the independence of the members of the remuneration committee: a priori, at each period they could adjust managers' compensation to actual achievement. The issue is the choice between an automatic rule and pure discretion.

But, for most economists, only competition can govern this complex process. If CEOs divert too many resources from an efficient allocation the undervaluation of the firm on the stock market will trigger a hostile take-over. In order to prevent such a take-over, the 
TABLE 1

How efficient are the various methods of controlling managers?

\begin{tabular}{|c|c|c|}
\hline Device & Rationale & Limits \\
\hline \multicolumn{3}{|l|}{ Incentive pay } \\
\hline $\begin{array}{l}\text { Indexing wage on } \\
\text { performance }\end{array}$ & $\begin{array}{l}\text { Aligning managers' and } \\
\text { rank-and-file workers' interests }\end{array}$ & $\begin{array}{l}\text { Possible manipulation of } \\
\text { performance by managers }\end{array}$ \\
\hline Bonus linked to profit & $\begin{array}{l}\text { Aligning managers' interests } \\
\text { and firm strategy }\end{array}$ & \\
\hline Stock options & $\begin{array}{l}\text { Aligning CEO interest with } \\
\text { shareholders' wealth }\end{array}$ & $\begin{array}{l}\text { Still a major gap between CEO } \\
\text { and shareholders' interests }\end{array}$ \\
\hline $\begin{array}{l}\text { Attribution of stock } \\
\text { of the company }\end{array}$ & $\begin{array}{l}\text { Aligning CEO interest with } \\
\text { shareholders' wealth }\end{array}$ & $\begin{array}{l}\text { Loosely correlated with CEO } \\
\text { strategy and large benefits } \\
\text { during financial bubble }\end{array}$ \\
\hline \multicolumn{3}{|l|}{ Transparency } \\
\hline $\begin{array}{l}\text { Public disclosure of } \\
\text { CEO's remuneration }\end{array}$ & $\begin{array}{l}\text { Trigger outrage from } \\
\text { shareholders and institutional } \\
\text { investors }\end{array}$ & $\begin{array}{l}\text { Camouflage tactic by managers } \\
\text { in spite of statements in favour } \\
\text { of transparency }\end{array}$ \\
\hline \multicolumn{3}{|l|}{ Remuneration setting } \\
\hline $\begin{array}{l}\text { Creation of an independent } \\
\text { remuneration committee }\end{array}$ & $\begin{array}{l}\text { Prevent self-determination } \\
\text { of remuneration by CEOs }\end{array}$ & $\begin{array}{l}\text { The CEO may largely control } \\
\text { the committee }\end{array}$ \\
\hline $\begin{array}{l}\text { Large number of independent } \\
\text { members of the board }\end{array}$ & $\begin{array}{l}\text { Prevent excessive remuneration } \\
\text { to the detriment of shareholders }\end{array}$ & $\begin{array}{l}\text { The income of members may } \\
\text { depend on their generosity to } \\
\text { the manager. }\end{array}$ \\
\hline $\begin{array}{l}\text { Survey by consultant firms of } \\
\text { CEO remuneration. }\end{array}$ & Set an objective benchmark & $\begin{array}{l}\text { The reference to average or } \\
\text { median remuneration induces } \\
\text { spill-over and excessive pay } \\
\text { increases }\end{array}$ \\
\hline \multicolumn{3}{|l|}{ Market for corporate governance } \\
\hline Firing of CEOs & Incentive to commitment & $\begin{array}{l}\text { Exceptional configuration in } \\
\text { the past }\end{array}$ \\
\hline Threat of take-over & $\begin{array}{l}\text { Puts a limit on CEO } \\
\text { opportunism }\end{array}$ & $\begin{array}{l}\text { Golden parachute for losers } \\
\text { CEO income may increase even } \\
\text { if shareholders suffer value } \\
\text { destruction }\end{array}$ \\
\hline
\end{tabular}

Source: Inspired by Bebchuk \& Fried (2003).

board should ex ante limit the opportunistic behaviour of top managers. The last-resort threat is, of course, bankruptcy. Back in the 1960s and 1970s large corporations were supposed to be 'too big to fail' but such is no longer the case. But, if bankruptcy is the last-resort deterrent against excessive $\mathrm{CEO}$ remuneration and bad managers, there is a more common mechanism, i.e. the creation of a market for corporate governance. Actually, the firing of CEOs has become more frequent and the duration of employment of CEOs has been reduced, especially in the United States. For instance, the period of notice for executive 
directors was drastically reduced between 1994 and 2001 (PIRC 2003: 8). This is an interesting development, since it could work as a Smithian solution to CEO remuneration: the creation of a fully fledged market for managers could provide an objective basis for determining their value. But this is to assume that complete recognition and assessment of the quality of managers is possible, and it is not at all evident, given the idiosyncratic nature of managerial talents. After all, the net profit of a corporation is the outcome of the mix of complementary and specific assets, including executive talents (Biondi et al. 2004). Therefore, generally speaking, the market is unable to fix a price for managers.

Clearly, all these devices are far from implementing shareholder value, since they are all constrained (see Table 1, column 3). Managers can manipulate the index of performance, not least by means of dubious if not illegal accounting practices. During financial bubbles the tide of speculation enriches those CEOs who benefit from stock options but only a small fraction of the extra compensation is related to the quality of their management. Even when the bubble burst, it is quite surprising to note, some CEOs renegotiated their stock options in order to maintain their total remuneration. In 2001 the value of stock options granted to the CEOs of S\&P companies, America's largest, rose by 43.6 per cent in a year when the total return of those companies fell by almost 12 per cent (Economist 2003). Similarly, in 2002 the median pay of the 365 CEOs covered by Business Week increased by 5.9 per cent but the total returns of the S\&P 500 companies were down by 22 per cent (Johnson 2003).

Transparency is quite difficult to achieve, since part of the profitability of corporations derives from proprietary information, knowledge and technology. The public disclosure of CEO remuneration may trigger outrage from shareholders and institutional investors, but the more complex and diverse the compensation mechanisms the more easily managers can adapt their tactics and adopt camouflage. Similarly, independent directors and members of the board and remuneration committee are a priori desirable but do not necessarily overcome the large asymmetry of information and power between CEOs and those directors. Another mechanism may hinder the efficiency of remuneration committee: the directors and CEOs may belong to the same web of boards, so forming a network of mutual exchange of high remuneration (Economist 2003). Furthermore, the reference to the current remuneration of CEOs via surveys undertaken by remuneration consultants may have perverse effects: the reference to average or median remuneration generally triggers a spill-over of excessive increases. Last but not least, the frequent negotiation of golden parachutes even for the least successful CEOs drastically reduces the incentive for managers to be efficient and fulfil shareholder value and wealth creation.

\section{From Optimal Contracting to a Managerial Power Approach}

Both the historical retrospective study of US corporations and the conclusions derived from transaction costs and principal/agent theory confirm that it is quite difficult to monitor executives in order to comply with the objective of profit maximization or shareholder value promotion. Therefore it is not surprising to observe during the 2000s a disparity between still booming executive compensation and poor stock market performance. This suggests that the normative theory of CEO compensation should be completed by another approach. One of the best candidate stresses entrenched managerial power (Bebchuk \& Fried 2003) and it enlightens the apparent paradox that optimal contracting recurrently faces.

Here the diagnosis is quite different (Table 2). For optimal contracting, the opportunistic behaviour of managers should be controlled by the strengthening of competition on product, labour and corporate governance markets. More precisely, the recognition of 
TABLE 2

Two approaches to the control of managers

\begin{tabular}{lll}
\hline Optimal contracting & Managerial power \\
\hline $\begin{array}{l}\text { Diagnosis } \\
\text { Opportunistic behaviour of managers }\end{array}$ & $\begin{array}{l}\text { Minimize outrage, via camouflage } \\
\text { Enthusiasm about equity-based compensation } \\
\text { control are not sufficient }\end{array}$ \\
$\begin{array}{l}\text { Solution } \\
\text { Design incentive pay systems. Managers' } \\
\text { behaviour optimizes value creation } \\
\text { and/or shareholder wealth }\end{array}$ & $\begin{array}{l}\text { Compensation consultants justify executive } \\
\text { pay CEOs control the board in charge of their } \\
\text { remuneration }\end{array}$ \\
$\begin{array}{l}\text { Adverse effects } \\
\text { Managers reap windfall income via stock } \\
\text { price increase independent of their actions }\end{array}$ & $\begin{array}{l}\text { Option plans that filter out windfalls are not in } \\
\text { the interests of managers. Therefore they are } \\
\text { not used }\end{array}$ \\
$\begin{array}{l}\text { The threat of take-over should discipline } \\
\text { CEOs }\end{array}$ & $\begin{array}{l}\text { Mergers and acquisitions justify higher } \\
\text { compensation of managers but do not always } \\
\text { increase shareholder value }\end{array}$ \\
\hline
\end{tabular}

Notes:

a 2000: CEO compensation was an average $7.89 \%$ of corporate profits in firms making up the 1500 company exe comp data set (Balsam 2002).

b 2001: 5\% of 250 largest US public firms used some form of reduced windfall options (Levinston 2001).

Source: Inspired by Bebchuk \& Fried (2003).

value creation and shareholder value should be imposed on managers as a core if not a unique incentive mechanism. The managerial power theory develops a more Machiavellian vision: in order to minimize the outrage of shareholder and public opinion, managers adopt camouflage strategies. Similarly, the enthusiasm of investors for equity-based compensation is adopted and used by CEOs who thereby find a justification for large increases in their incomes. Whereas in the 1960s and 1970s executive wages were defined as a multiple of median workers' income, during the 1990s the larger part of their income was related to the flow of profit or the appreciation of their shares. Hence a device that was supposed to discipline managers has actually been distorted in order to extend their wealth to unprecedented levels (see Figure 10).

Any reference to market benchmarking for CEO compensation may have the effect not of disciplining the remuneration committee but of triggering spill-over and escalation, whereby less well paid managers ask for median or average pay, which in turn raises average pay and thus initiates a vicious circle. Similarly, the shift from indexation of pay related to profit or cash flows to stock options is not without risk. First, the stock market valuation takes into account the macroeconomic situation, the level of short-term interest rate and sectoral effects, and does not exclusively gauge the contribution of the managers to the prosperity of the joint-stock corporation. Furthermore, there are a lot of stochastic elements and mimetism in the valuation of a firm. It is therefore risky not to filter stock market value by 
these macro and sectoral determinants. Second, and still more important, the net profit of any firm does not result from the optimal mix of substitutable standardized factors valued on the market. Almost by definition, higher than average profit rates derive from the complementarity of firm-specific assets: among these, the talents of the manager cannot be measured by a typical competitive market. Third, today's decisions of top executives lead to tomorrow's investments and the products/profits of the day after tomorrow. Stock options that can be used over a short period of time cannot capture the necessary long-term orientation of an efficient pay system.

This confirms the merit of the managerial power approach in explaining these features that are at odds with the predictions of optimal contracting. Option plans that filter out windfalls are not in the interest of CEOs. Mergers and acquisitions frequently destroy value instead of creating it, but the executives nearly always increase their compensation along with the size of the corporation. More fundamentally, CEOs by definition have access to insider information ${ }^{1}$ and they are generally better informed of the specific sources of competitiveness in their firm than financial analysts working outside the firm. Even the most highly specialized analysts, who are experts in crunching financial data and gleaning ad hoc information during roadshows, are rarely able to capture the intrinsic assets and liabilities of a firm.

\section{Controlling and rewarding Managers: an Issue of Political Economy}

If the managerial joint-stock corporation is not more efficient and does not increase its share via the selective mechanisms of competition - both in product and financial markets - how should we explain the boom in CEO remuneration during the 1990s? Nearly all countries are affected, and the trend persists in spite of suspicion from minority shareholders and in the face of hostile public opinion. For instance, in France one still observes diverging trends of CEO remuneration and financial results for a significant number of corporations (see appendix). This article proposes a twofold explanation.

1 First, history suggests that managers have always been part of the leading alliance, reaching an accommodation successively with various groups. The novelty of the present period is an alliance with finance, at odds with the Golden Age of Fordism, when a compromise was struck with wage earners.

2 Second, there is a more theoretical and structural reason for this hegemonic role of managers. Where does the profit of any firm come from? Basically, from the idiosyncratic mix of firm-specific assets, and it is precisely the role of managers to organize the related complementarity such that they have significant autonomy in deploying their strategies and still more in informing outsiders about the financial situation of the firm.

\section{Managers are the Centre of Shifting Alliances, most recently with Financiers}

The current bargaining position of executives is the outcome of a series of long-run transformations in the relations between wage earners, consumers, financial markets, the international economy and the nation State. Three quite distinct periods can be distinguished.

The 1960s: an alliance between wage earners and managers in the Fordist growth regime. This period has already been mentioned by the brief history of the concept and the forces 




Fig. 4. The 1960s. The first configuration of actors: the Fordist compromise.

that shape the modern corporation. Actually the 1960s experienced a quite atypical accommodation between wage earners and managers. Given the strong bargaining power of trade unions, the pro-labour orientation of many governments and the high control over finance via a series of national regulations, a Sloanist corporation was built upon three premises. First, workers accept modern production methods and productivity increases in exchange for indexation of real wages to productivity (Aglietta 1982; Boyer \& Juillard 2002). This creates a large market for mass production and sustains the multidivisional and large conglomerates (Boyer \& Freyssenet 2002). Second, professional managers see themselves as wage earners and express their income as a multiple of the average wage. Third, financial markets are not in a position to exert a strong influence on the strategic choices of corporations. This de facto alliance of managers with wage earners triggers an unprecedented growth regime. Its economic benefits easily sustain the related social compromise (Figure 4). Paradoxically, this period was perceived by contemporary analysts as highly prone to conflict between labour and capital, whereas in retrospect the demand for higher wages and better welfare were highly functional for the growth regime.

The 1980s: internationalization erodes the old alliance. But such a regime was not to last for ever: its very success triggered adverse trends such as accelerating inflation, rising unemployment and more basically a degree of internationalization that progressively eroded the alliance between managers and wage earners. Whereas the international regime was highly permissive in the 1960s, recurring external trade deficits put the question of competitiveness of firms at the centre of the political and economic agenda. Corporations had to restructure their organization and frequently slim down their work force, and this was quite a drastic reversal with respect to the previous Fordist compromise. During this period competition in product markets puts consumers at the forefront, who are seen as gaining from external competition via moderation of the prices of imported manufactured goods. The competitiveness motive is invoked by managers in order to rewrite labour contracts and internationalization becomes the main preoccupation of governments. In a sense, the sovereignty of consumers plays the role of an enforcement mechanism in order to discipline workers, and managers cleverly used this device (Figure 5). Implicitly at least, managers invoked the role of consumer demand in the context of more acute international 


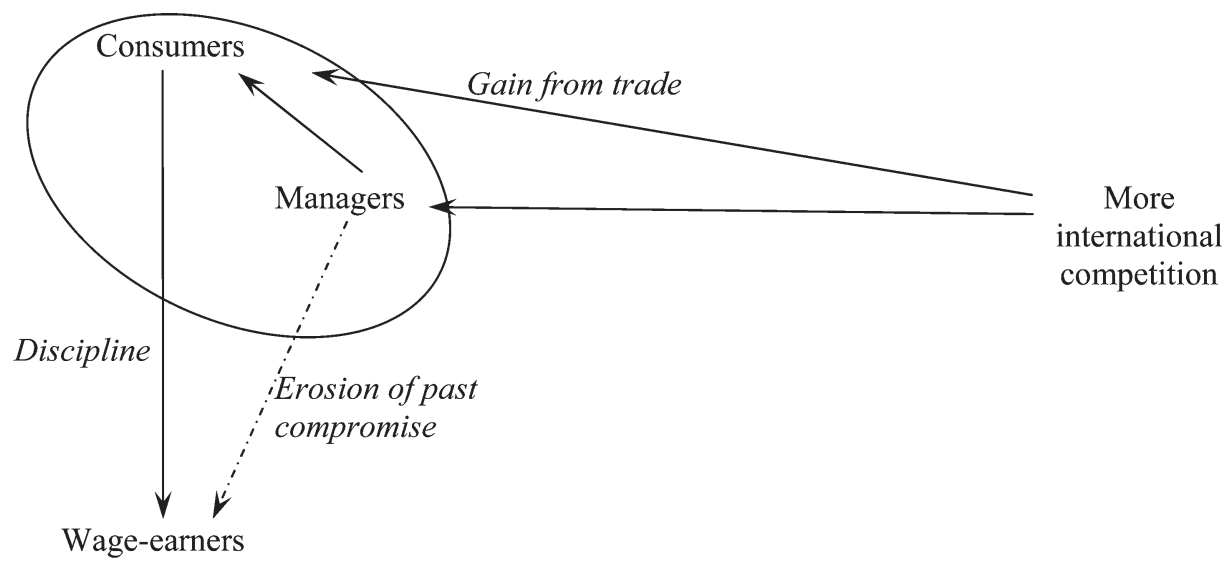

Strong links

Weak links $\longrightarrow$ Direction of influence

Fig. 5. The 1980s. The second configuration of actors: an international competition-led regime.

competition, in order to impose or negotiate a new configuration of the wage/labour nexus. During this period the adjustments required by a rather turbulent international economy involved greater risk sharing by workers via flexibility of hours, the revision of the laws protecting employment and, of course, greater flexibility of wages and the slimming down of welfare.

The 1990s: under the rubric of shareholder value, a hidden alliance of managers with financiers. The internationalization of production has not been the only feature of the last two decades. Since the mid-1980s financial liberalization, the multiplicity of financial innovations and their diffusion from the United States to the rest of the world have drastically changed the conception of corporate governance as well as the conduct of economic policy. The conventional view is that joint-stock corporations in the manufacturing and service sectors have been submitted to the strong requirements of institutional investors. The power of these new players precisely derives from financial deregulation, and the high mobility of capital entitles them to demand changes in the rules of the game: higher rates of return on invested capital, profits that meet forecasts and financial analysts' expectations, and a steady flow of profits generated by the corporations. In the United States, and to a lesser extent in the United Kingdom, a finance-led growth regime has replaced the Fordist one, but the relevance of this model was not warranted in countries such as Germany or Japan (Boyer 2000). In spite of this divergence in national growth regimes, the ideal of shareholder value, or at least its rhetoric, has been diffused all over the globe.

Nevertheless, closer investigation suggests a more nuanced appraisal. Given the fad promoted by financial investors around the promotion of stock options, and the support of many experts in corporate finance, the objective of realigning the interests of shareholders and managers has been widely diffused, first in the United States, then in many other OECD countries. Cleverly, without necessarily admitting it openly, managers have used the demands of institutional investors to redesign their own compensation. On top of their salary, many forms of remuneration related to profit and stock market valuation have therefore been evolving, and they have drastically increased the total income of CEOs (see Figure 11). Top executives have been practising the art of judoka: converting the 




Strong links

Weak links $\longrightarrow$ Direction of influence

Fig. 6. The 1990s. The third configuration of actors: the alliance of investors and managers.

pressure of the financial community into a counter-move that benefits them and continues to erode the bargaining power of wage earners.

Thus, beneath the tyranny of investors, an implicit alliance between managers and investors takes place, and wage earners have to submit to a new wave of labour market deregulation (Figure 6). For instance, they have to bear a greater share of risk, so as to stabilize corporate rates of return, and to avoid the elimination of their jobs. The wage/ labour nexus itself is transformed accordingly. First of all, the shift from pay-as-you-go pension schemes to pension funds generates a huge inflow of savings into the stock market (Montagne 2003), and this propels a finance-led growth regime in the United States. Second, in order to try to compensate for very modest wage increases, permanent workers accept various forms of profit sharing, and even gain access to shares in their company via special schemes. Managers have been reorienting their alliances, and this has definite consequences for macroeconomic patterns, régulation modes, income inequality and even economic policy formation.

\section{The Power and Informational Asymmetry in Favour of Executives}

How can we explain this pivotal role of managers? A political economy approach suggests one interpretation: given their position in the firm, structurally managers are able to exert power within the economic sphere. Power relations are not limited to the political sphere: they exist in other guises in the economy (Lordon 2002). Many factors may explain a clear asymmetry both with respect to labour and to finance:

1 First, a mundane observation: executives make decisions on an everyday basis and directly affect the strategy of the firm. By contrast, boards exercise control at a low frequency, the control exerted by financial analysts is only indirect and in most OECD countries wage earners have no say in the management of the firm they work for.

2 Therefore managers built up special knowledge and competences that are not revealed to financial markets, competitors or representatives of labour. External financial analysts may gather statistical information about the firm and its competitors, but the real sources of profitability may still be hard to pin down from lack of familiarity with the details of particular corporate success and its determinants. 
3 By definition, no insider information should be revealed or divulged to outsiders, since it might well be the source of extra profits. There is therefore a clear incentive to use such information strategically and opportunistically. Of course, insider trading on the stock market is illegal, but the everyday use of insider information and knowledge is not.

4 There is a strong asymmetry of power and information between the top managers and the various boards and committees. Members of the latter are appointed by the executives, the information they are given is assembled by the staff of the corporation, and, finally, the members of the board tend to belong to the same social network. Thus the probability of the agenda and the proposals put forward by the CEO being accepted is quite high. Similarly, during the general meeting of shareholders, minorities do not have the resources to put forward alternative nomination and proposals (Bebchuk 2004). Therefore the control of managers by auditors, financial analysts and shareholder organizations is exercised ex post and generally when the situation has become dramatic. Fine tuning the control of managers is difficult indeed.

All these arguments derive from the same central feature of profit generation. The patrimonial conception of the corporation assumes that profit derives from the mix of substitutable and generic factors of production, according to the prevailing system of prices. The basic hypothesis is that each factor is paid according to its marginal productivity. This model breaks down as soon as an organic conception is adopted: the corporation is defined by a set of complementary competences that are difficult to replicate. This is the source of the net profit of the firm (after interest payments). In effect, the entrenched power of executives is the mirror image of the ability of the firm to generate profits. It is therefore illusory to think that traders on the financial markets can know better than the managers the origin and causes of the success of a given corporation. Their informational advantage derives from statistical analysis of the macro and sectoral determinants of a sample of firms belonging to the same sector.

When the Financial Crises and Scandals erupt, two new Players: the Lawyer and the Activist The bursting of the Internet bubble in the United States and the financial scandals that affected the United States and many other OECD countries again shifted the previous alliances. Paradoxically, the instability of the finance-led growth regime could have been predicted, and the history of financial crises reveals that the situation in the 2000s is not totally new. Two new actors then enter into the plot.

Whatever the conflict of interest, the lawyers always win. Given the role of lawyers and the judiciary in the United States, it is no surprise to observe that the excess of greed of some managers has entailed the multiplication of lawsuits whereby disappointed shareholders or wage earners made redundant demand compensation from top executives. But, since the responsibility for problems is shared among a whole spectrum of professionals (institutional investors, financial analysts, auditors, rating agencies and fund managers and, of course, corporate managers), this is a wonderful opportunity for lawyers to extract a quasi-secure income: whoever wins the case, lawyers benefit from a positive and substantial fee! The key role of these players probably means the disruption of the previous alliance between managers and financiers (Figure 7).

Public concern about financial regulation: domestic and international activists. Two final actors have to be brought into the picture. First, households that have lost a significant part of their capital do complain and may sue joint-stock corporations, pension funds, financial 


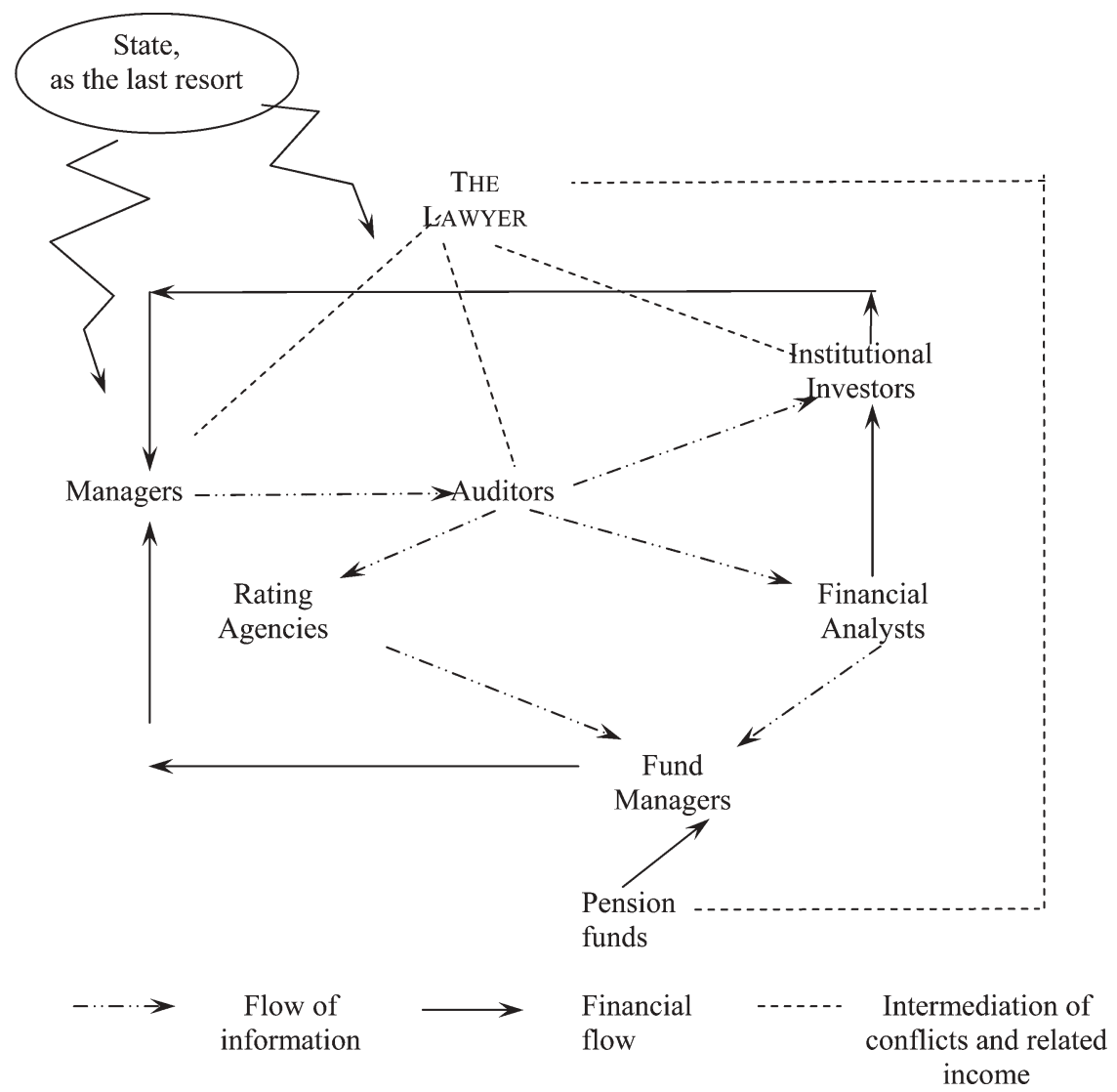

Fig. 7. The 2000s in the US. The fourth configuration of actors: the lawyer wins, whatever the situation.

analysts and institutional investors. Second, activists make their voices heard demanding reform of the law on the responsibility of managers and financial intermediaries. Both domestic and international activists focus their criticisms and demands for reform on finance: the latter complain about the social cost of globalization, including financial globalization (Figure 8). The only way of converting these voices into action is by pressing the State to pass laws to try and curb the power of corporations and institutional investors. This is essentially a matter of domestic policy. Where the financial scandals have been most acute, new Bills have been passed, such as the Sarbanes-Oxley Act in the United States.

\section{The Power of Managers at the Firm Level: Much converging Empirical Evidence}

In many of the previous configurations, top managers have a pivotal role, since they develop alliances with other social groups and these alliances vary according to the institutional, political and economic context. The previous hypothesis about the intrinsic power of 


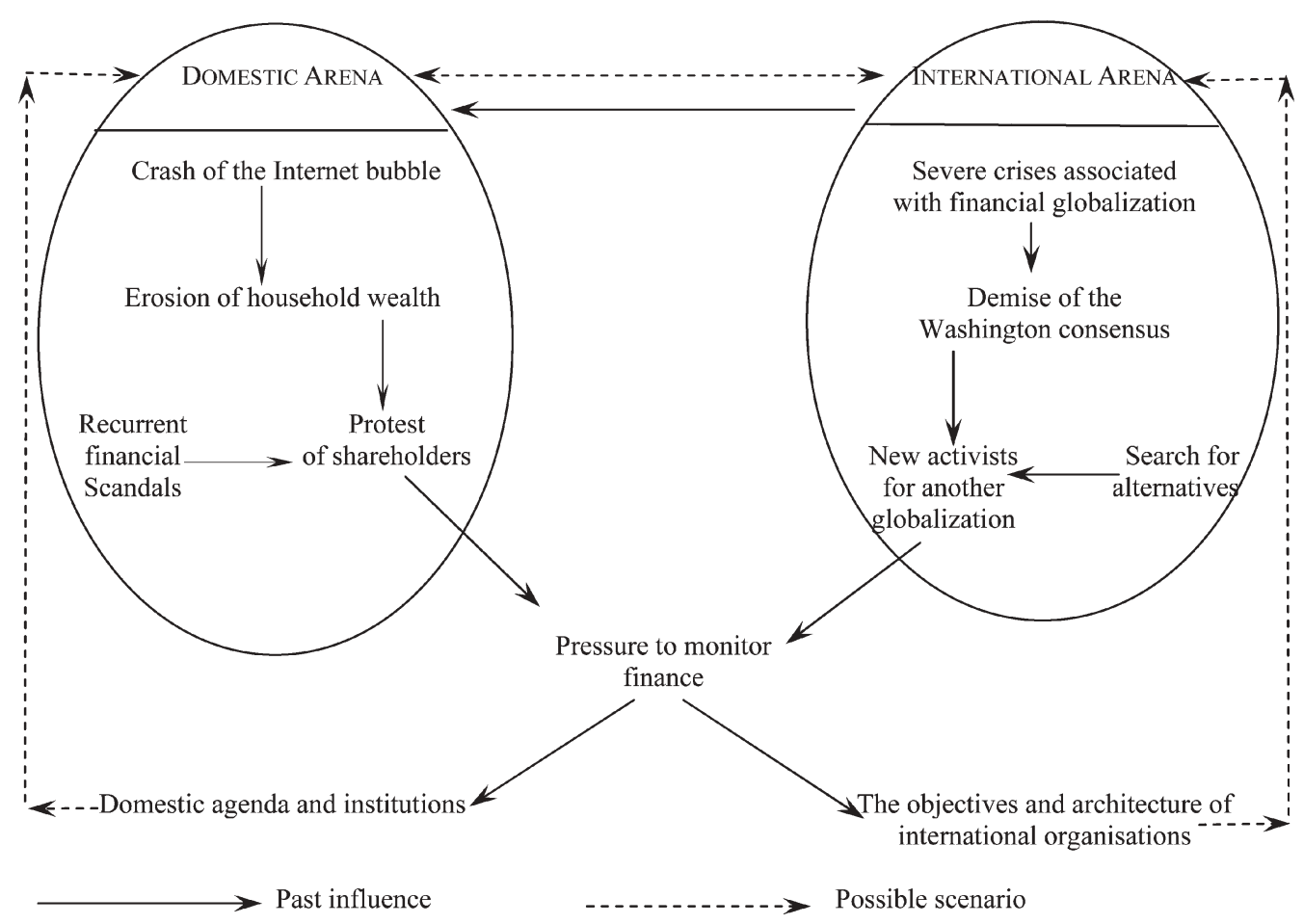

Fig. 8. The 2000s. The fifth configuration of actors: the threat of State intervention in order to discipline global finance.

managers, at both the micro and the macro level, is difficult to test fully and directly, but much scattered evidence suggests the existence and permanence of such a power.

\section{Insider Trading: a Manifest Use of Strategic Information}

Top managers and members of the board of directors of publicly traded corporations possess more information about their company than the individual shareholder or even professional analysts. Given this asymmetry, insider trading conveys some information to outsiders, and this may contribute to the efficiency of the stock market. Generally the literature finds that stock prices increase after publicly announced grants of stock options to executives (Yermack 1997). Two opposing interpretations might be given to this phenomenon. Either the incentive mechanisms of stock options trigger better management that is afterwards translated into more profits and higher stock market prices. Or executives time their option grants in anticipation of news which may be likely to boost stock prices.

A recent study of UK listed companies (Fidrmuc et al. 2003) does confirm that market reaction to the announcement of directors' purchases is positive and, conversely, that the announcement of directors' sales induces a decline in the stock market. The mere observation of the sequence of announcements and returns suggests that the second hypothesis is likely. In fact, insider purchases are associated with a prior decline in the rate of return and, conversely, insider sales are observed after a period of abnormal positive returns. This could be a sign of strategic behaviour by managers and directors. 


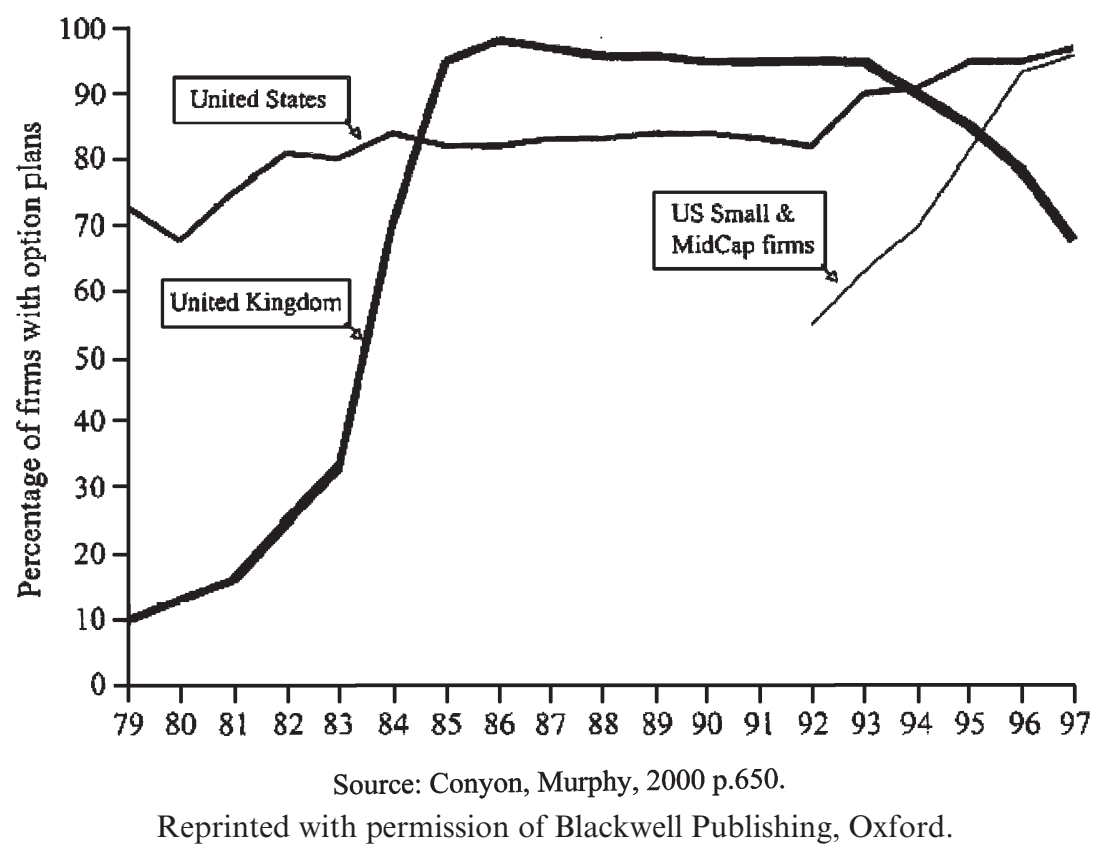

Fig. 9. The contrasted patterns of stock option diffusion in the US and UK.

\section{The Diffusion of Stock Option Plans: a Response to Shareholder Value}

If, in theory, stock options are supposed to discipline managers according to the interests of shareholders, the idea cannot be excluded that managers use this pressure in order to increase their total compensation. Such a hypothesis comes out from a comparison of CEO pay in the United States and the United Kingdom (Conyon \& Murphy 2000).

First, the timing of the diffusion of stock option plans is quite different in the two countries. In the United States the top executives of the S\&P 500 have regularly benefited from stock option plans since the 1980s and they experienced a new increase in this frequency during the 1990s. What was new in the 1990s was the diffusion to small and medium-capitalization firms of this type of remuneration for executives (Figure 9). In the United Kingdom the pattern of diffusion is U-shaped, with stock options almost nonexistent in the early 1980s, followed by widespread diffusion until they reach a plateau, followed by decline since 1993. These contrasting trajectories could sustain the hypothesis that the unequal maturation of financial markets, including the diffusion of pension funds, may explain the differences observed in the structure of the remuneration of top executives in both countries.

Actually, the structure of CEO compensation is quite different in each country. In the United Kingdom, base salary is the largest element of total compensation, annual bonus is a secondary source of remuneration, whereas option grants represent only 10 per cent of total CEO compensation. By contrast, in the United States, base salary is less than a third of CEO compensation, while stock options represent the largest source of income for top executives (Table 3). Total pay doubles in the United Kingdom only when the size of the firm goes from less than $£ 200$ million to more than $£ 1.5$ billion, but in the United States this remuneration is multiplied by more than six times for the same range of size. Lastly, the United States 
TABLE 3

Differing structures of CEO compensation in the UK and the US, 1997

\begin{tabular}{|c|c|c|c|c|c|c|c|c|}
\hline \multirow[t]{2}{*}{ Group } & \multirow[b]{2}{*}{$\begin{array}{l}\text { Sample } \\
\text { firms }\end{array}$} & \multicolumn{2}{|c|}{ Total pay $(£ 000)$} & \multicolumn{5}{|c|}{ Average composition of total pay $(\%)$} \\
\hline & & Average & Median & $\begin{array}{l}\text { Base } \\
\text { salary }\end{array}$ & $\begin{array}{l}\text { Annual } \\
\text { bonus }\end{array}$ & $\begin{array}{l}\text { Option } \\
\text { grant }\end{array}$ & $\begin{array}{l}\text { LTIP } \\
\text { shares }\end{array}$ & $\begin{array}{l}\text { Other } \\
\text { pay }\end{array}$ \\
\hline \multicolumn{9}{|l|}{ United Kingdom } \\
\hline $\begin{array}{l}\text { All companies } \\
\text { By firm sales ( } £ \text { million) }\end{array}$ & 510 & 589 & 414 & 59 & 18 & 10 & 9 & 5 \\
\hline Less than 200 & 152 & 452 & 287 & 64 & 17 & 10 & 4 & 5 \\
\hline $200-500$ & 119 & 403 & 335 & 61 & 19 & 8 & 6 & 6 \\
\hline $500-1,500$ & 116 & 601 & 507 & 54 & 20 & 10 & 12 & 4 \\
\hline Above 1,500 & 123 & 927 & 811 & 55 & 16 & 10 & 15 & 4 \\
\hline \multicolumn{9}{|l|}{ By industry } \\
\hline Mining/manufacturing & 217 & 564 & 436 & 59 & 17 & 9 & 9 & 5 \\
\hline Financial services & 84 & 559 & 411 & 60 & 22 & 6 & 7 & 4 \\
\hline Utilities & 19 & 448 & 382 & 58 & 15 & 6 & 14 & 8 \\
\hline Other & 190 & 645 & 397 & 58 & 17 & 11 & 8 & 5 \\
\hline \multicolumn{9}{|l|}{ United States } \\
\hline All companies & 1,666 & 3,565 & 1,508 & 29 & 17 & 42 & 4 & 8 \\
\hline \multicolumn{9}{|c|}{ By firm sales ( $£$ million) } \\
\hline Less than 200 & 339 & 1,166 & 686 & 38 & 14 & 43 & 1 & 4 \\
\hline $200-500$ & 379 & 1,833 & 926 & 36 & 18 & 36 & 3 & 7 \\
\hline $500-1,500$ & 458 & 3,038 & 1,604 & 28 & 18 & 40 & 5 & 9 \\
\hline Above 1,500 & 490 & 7,056 & 3,552 & 20 & 17 & 48 & 5 & 10 \\
\hline \multicolumn{9}{|l|}{ By industry } \\
\hline Mining/manufacturing & 842 & 3,388 & 1,540 & 28 & 17 & 43 & 3 & 8 \\
\hline Financial services & 198 & 6,277 & 2,787 & 19 & 20 & 47 & 5 & 8 \\
\hline Utilities & 120 & 1,333 & 707 & 43 & 15 & 23 & 6 & 13 \\
\hline Other & 506 & 3,326 & 1,438 & 32 & 16 & 43 & 3 & 6 \\
\hline
\end{tabular}

Source: Conyon and Murphy (2000: 646).

displays an interesting feature: CEO remuneration is far higher in financial services, nearly double average remuneration, and option grants in this sector are the major source of total compensation. This is further evidence of the financialization of corporate remuneration that starts in the financial sector and then diffuses to other sectors.

The divergence of CEOs remuneration between the United Kingdom and the United States is confirmed by the most recent studies that provide data for the early 2000s (Erturk et al. 2005). The CEOs of the FTSE 100 receive 74.5 per cent of their compensation by way of basic pay, whereas the share of base salary is only 11.5 per cent for CEOs running S\&P 500 companies. Conversely, cashed options are more than 71.2 per cent of total compensation of the largest quoted American companies. These findings are congruent with the general hypothesis that shareholder value has permeated American corporations more easily than British ones. Thus American managers have been able to capture a larger remuneration via the adoption of stock option plans. 
TABLE 4

Statistics for stock-based CEO incentives by size

\begin{tabular}{|c|c|c|c|c|c|c|c|c|}
\hline \multirow[t]{2}{*}{ Group } & \multicolumn{2}{|c|}{$\begin{array}{l}\text { Share holdings } \\
\text { (£ million) }\end{array}$} & \multicolumn{2}{|c|}{$\begin{array}{l}\text { Share holdings } \\
\text { ( } \% \text { of common) }\end{array}$} & \multicolumn{2}{|c|}{$\begin{array}{l}\text { Option holdings } \\
\text { ( } \% \text { of common) }\end{array}$} & \multicolumn{2}{|c|}{$\begin{array}{l}\text { Pay/performance } \\
\text { sensitivity }(\%)\end{array}$} \\
\hline & Average & Median & Average & Median & Average & Median & Average & Median \\
\hline \multicolumn{9}{|l|}{ United Kingdom } \\
\hline All companies & 7.01 & 0.46 & 2.13 & 0.05 & 0.24 & 0.11 & 2.33 & 0.25 \\
\hline \multicolumn{9}{|c|}{ By firm sales (million): } \\
\hline Less than $£ 200$ & 9.86 & 1.41 & 4.38 & 0.63 & 0.38 & 0.21 & 4.72 & 1.09 \\
\hline$£ 200$ to $£ 500$ & 9.50 & 0.70 & 2.55 & 0.14 & 0.24 & 0.14 & 2.75 & 0.42 \\
\hline$£ 500$ to $£ 1,500$ & 4.55 & 0.13 & 0.76 & 0.02 & 0.19 & 0.12 & 0.91 & 0.16 \\
\hline Above $£ 1,500$ & 3.40 & 0.33 & 0.21 & 0.01 & 0.10 & 0.04 & 0.31 & 0.05 \\
\hline \multicolumn{9}{|l|}{ United States } \\
\hline All companies & 60.37 & 3.26 & 3.10 & 0.29 & 1.18 & 0.72 & 4.18 & 1.48 \\
\hline \multicolumn{9}{|c|}{ By firm sales (million): } \\
\hline Less than $£ 200$ & 16.63 & 2.07 & 5.32 & 0.96 & 1.84 & 1.37 & 6.98 & 3.65 \\
\hline$£ 200$ to $£ 500$ & 23.84 & 2.93 & 3.94 & 0.58 & 1.39 & 0.94 & 5.20 & 2.05 \\
\hline$£ 500$ to $£ 1,500$ & 32.25 & 2.64 & 2.36 & 0.25 & 1.12 & 0.70 & 3.43 & 1.26 \\
\hline Above $£ 1,500$ & 145.26 & 4.96 & 1.61 & 0.09 & 0.62 & 0.40 & 2.17 & 0.56 \\
\hline
\end{tabular}

Source: Conyon and Murphy (2000: 655).

\section{The Larger the Corporation the Less the CEO Pay/Performance Sensitivity}

If the hypothesis that stock options were designed as an incentive mechanism in order to control the opportunistic behaviour of those CEOs in charge of the large quoted corporations, we should observe greater responsiveness of CEOs' compensation as the size of the company increases. Quasi-unanimously the econometric literature finds the opposite result. For instance, Conyon \& Murphy (2000) find that the pay/performance sensitivity is about 0.07 for small companies but only 0.02 for the largest ones in the United States. Similar results emerge from the British data: pay/performance sensitivity is around 0.05 for small companies and decreases relentlessly along with size (only 0.003 for the largest companies; Table 4). Of course, this is not necessarily evidence of the immunization of large corporations' CEOs from the market's evaluation of their performance. Rather, the estimated coefficient combines the impact of the size and the elasticity of CEO remuneration.

There is more evidence of significant autonomy in the determination of CEO remuneration: the mechanism of stock options itself gives them room for manoeuvre. If the options are under water, CEOs suffer no downward adjustment of their actual remuneration, since the only loss is unseen, thanks to the gap between the actual performance of the company on the stock market and that which was expected when the stock options were granted. Conversely, exceptional performance by the company is rarely rewarded with an increase of the volume of stock options (Stathopoulos et al. 2005).

The Surge in Mergers and Acquisitions: a Benefit for the Managers, less often for Shareholders

Additional evidence of the power of CEOs can be found by considering the merger mania of the 1990s and previous episodes. On the one hand, most studies find no correlation 
between financial performance and the size of quoted companies (Main et al. 1995). On the other, total CEO remuneration clearly increases with size, especially in the United States (Ertuk et al. 2005). Consequently, although shareholders would be likely to be interested in a cautious approach to external growth, CEOs usually have a different vision: big is beautiful, especially for their remuneration. Therefore if the financial markets are highly liquid, and if a financial bubble distorts the valuation of the company, it is very tempting for CEOs to use mergers and acquisitions in order to expand their turnover and the capital they control.

These conditions were precisely fulfilled in the US stock market during the 1990s: once again, a merger mania was rife in spite of the robust evidence that previous episodes have generally been quite detrimental to the rate of return of the companies that embarked on mergers and acquisitions (Kaplan 2000). The Internet bubble was no exception: ex post it is clear that the start-ups of the new economy have globally been destroying stock market value, whilst the so-called mature industries have been more profitable than the sunrise industries. Nevertheless, the compensation of CEOs has rocketed, largely owing to the fact that the speculative wave lifted nearly all stock market prices, regardless of the company.

This is fresh evidence of the implicit alliance between CEOs and top executives, on the one hand, and between investment banks and high-level financiers on the other. The former group enjoyed rapid rises in their total remuneration, while the latter group were able to generate larger and larger profits, by the multiplication of the fees associated with merger and acquisition operations and active portfolio management, for example on behalf of pension funds. The average shareholder saw only a fraction of the total financial gains, precisely because operational costs have been increasing with the sophistication of financial methods. Thus, beneath the shareholder value rhetoric, an implicit alliance between the financial industry and top corporate management seems to have been at work during the 1990s (Figure 10).



Fig. 10. From the rhetoric to the reality of shareholder value. 


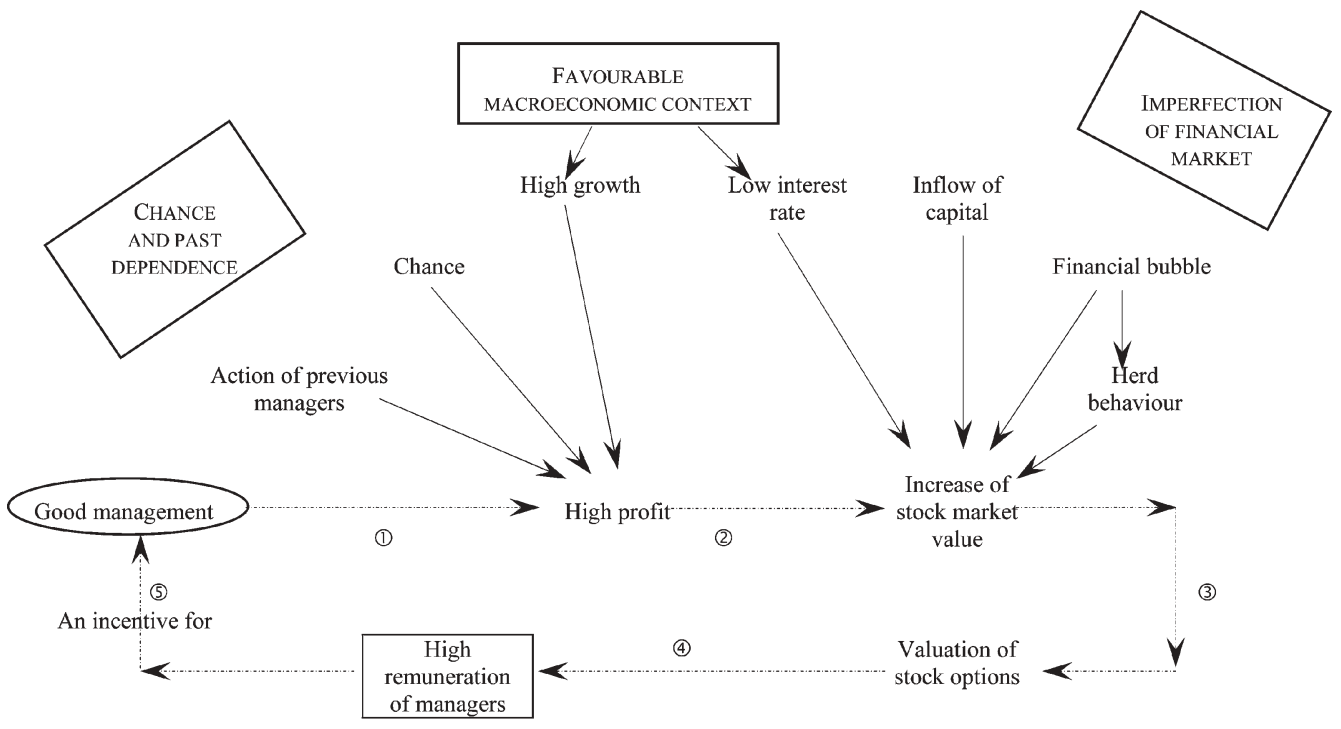

The expected, micro based, virtuous circle

The actual macroeconomic perturbations

Fig. 11. Why stock options do not sort out the contribution of managers to the performance of the corporation.

\section{Clear Windfall Profits for Managers benefiting from Stock Options}

The intensive use of stock options in the United States was supposed to align the strategies of CEOs with the interests of shareholders. It has already been argued that, at the micro level, such an alignment of interests can never be perfect. New sources of discrepancies also emerge when the firm is considered in the macroeconomic context (Figure 11):

1 First, the contemporary financial performance of a firm is largely shaped by the decisions taken by previous CEOs, given the large time lag between an investment (particularly research and development expenditure) and its impact on the competitiveness of the firm. Actually the time horizon of financial valuation by stock markets is far shorter than the time of maturation of innovation and productive investment. The car industry and even more so the biotech sector are good examples where such time lags may cover one or two decades.

2 There is a second source of discrepancy between stock options and the actual merits of CEOs. During the second half of the 1990s fast and stable growth with little inflation resulted in very low interest rates, thus generating and diffusing a speculative bubble that had no direct correlation with the quality of management (Boyer 2004). Bad and good managers benefited equally from the common belief that a new growth regime had emerged, and that profitd could only grow and thus sustain unprecedented rates of return on capital invested.

3 A third limit of stock options derives from the fact that financial markets are generally micro-efficient (i.e. in valuing the relative price of stocks) but macro-inefficient in the 
sense that they are not immune to poor intertemporal allocation of capital: overconfidence and mimetism are the response to the typical uncertainty of highly liquid financial markets, thus generating speculative bubbles (Orléan 1999). During such speculative periods the compensation of CEOs bears no clear relation to their contribution to the performance of the company they run.

These three mechanisms (path dependence and chance, the impact of the macroeconomic context and the imperfection of financial markets) totally distort the core virtuous circle envisaged by the proponents of stock options (Figure 11).

These divergences between the incentive mechanism of stock options at the micro-level and their macro-determinants have had a major impact in the skyrocketing of CEO remuneration from 1995 to 2000 (Erturk et al. 2005). If financial markets were perfect the distribution of dividends would be the only relevant performance indicator, as well as the source of remuneration for shareholders and CEOs benefiting from stock options. In reality, since the early 1980 s, the increase in the share price has represented between twothirds and three-quarters of the total return to shareholders. This is a rough approximation of the overvaluation of CEO compensation during this period.

\section{CEOs have Asymmetrical Power on the Remuneration Committee}

In large US corporations the compensation level of chief executives is set by a remuneration committee. The conventional wisdom states that independent board of directors safeguards shareholders' interests and reduces opportunism on the part of management. But neither social science theory nor empirical studies confirm this optimistic view (Main et al. 1995). From a theoretical standpoint, CEOs have at least three trump cards compared with the members of the remuneration committee:

1 The first bias in favour of top management may be termed cognitive: insiders such as CEOs have a better knowledge of the company's activities, strengths and weaknesses than outsiders. Furthermore, the executives and financial officers control the information issued to the various boards as well as to the financial markets. This first asymmetry is obvious when one considers the average time spent by independent directors in controlling corporate management as compared with the full-time activity of top executives.

2 Social psychology points out a series of other small-group mechanisms that come into play on the board of directors or/and remuneration committee. The principle of reciprocity plays a role in the escalation of remuneration, since the members of the board and CEOs tend to belong to the same closely knit social group. The respect due to the authority of the CEO is a second factor that may explain why top executives are overpaid with respect to an accurate assessment of their contribution to the performance of the firm. A third mechanism relates to similarity and potential liking for members of the same 'small world' (Temin 1999).

3 The issue of power introduces a third asymmetry between CEOs and members of the various boards. Who nominates whom? If the CEO is nominated before the remuneration committee, econometric studies show this has a positive impact upon the level of the CEO's remuneration, particularly when they can nominate economic variables that capture the performance of the corporation in a way that is likely to be advantageous in determining pay. 
In fact some econometric studies based on Business Week compensation surveys (as far back as 1985) confirm the prevalence of these asymmetries in favour of top executives (Main et al. 1995: 317-18). One interesting and one surprising results emerge. On one hand the ability of the board to monitor CEO performance and set pay appears greater in owner-controlled firms. On the other, CEO compensation is higher when the directors are independent! This is the exact opposite of the prognosis put forward by the advocates of transparent corporate governance.

\section{After 1997, a Favourite Corporate Strategy: Distorting the Profit Statements}

The relative autonomy of top executives, including CEOs and CFOs, is significant in relation to the information provided to capital markets. In this respect, the American system permits significant freedom in the interpretation of the general principles of accounting. In fact, during the Internet bubble, many firms used and abused this opportunity (Himmelberg \& Mahoney 2004). In retrospect, the overestimation of corporate profit is so large that the ex post accurate figures show a reduction of corporate profit after 1997, whereas ex ante, until July 2001, corporations had persistently announced an ongoing rise in their profits (Figure 12).

Such a discrepancy between real-time private information and ex post public evaluation in the American national accounts might have many sources. First of all, the accounting rules are not the same for corporate and national accounts, although this cannot explain the discrepancy shown in Figure 12, where the Bureau of Economic Analysis estimates have been elaborated using the same set of rules. A second and quite important source of discrepancy relates to an unexpected surge in employee stock options exercised

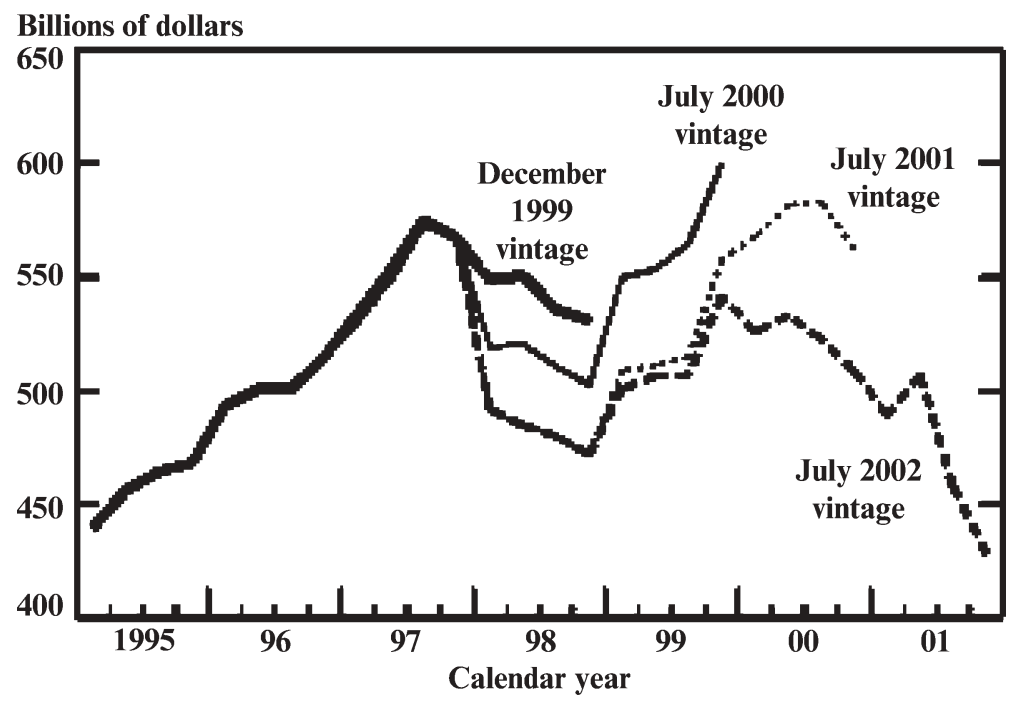

Source: Himmelberg and Mahoney (2004), p. 10.

Reproduced with permission of the Federal Reserve Board.

Fig. 12. The systematic overstatements of profits after 1997: as slow process of adjustment in the US. 
TABLE 5

Two evaluations of the impact of stock options on corporate profits in the US

\begin{tabular}{|c|c|c|c|c|}
\hline & \multicolumn{4}{|c|}{ Stock options exercised as a percentage of after corporate profit } \\
\hline & 1997 & 1998 & 1999 & 2000 \\
\hline Stock options exercised & 68.61 & 100.08 & 139.29 & 197.37 \\
\hline $\begin{array}{l}\text { Profit estimated by Bureau } \\
\text { of Economic analysis }\end{array}$ & 552.10 & 470.00 & 517.20 & 508.20 \\
\hline $\begin{array}{l}\text { Stock options exercised } \\
\text { compared with profit }\end{array}$ & 12.40 & 21.30 & 26.90 & 38.80 \\
\hline
\end{tabular}

Source: Himmelberg \& Mahoney (2004: 10).

\begin{tabular}{ccccc}
\hline & \multicolumn{4}{c}{ Options expenses as a percentage of net earnings for S\&P companies } \\
\cline { 2 - 5 } & 1996 & 1998 & 2000 & 2002 \\
\hline 2 & 5 & 8 & 23 \\
\hline
\end{tabular}

Source: The analyst's accounting observer in Business Week, 20 July 2003, p. 38.

during the second half of the 1990s. During this period, stock options were not regarded as a cost by corporations and were thus not expensed in the income statement. This contributed to the upward spiralling of stock markets: the shift of employee remuneration from basic wage to stock options increases corporate profit, leading to higher valuation of the corporation's shares and, finally, new incentives to award stock options to a broader category of personnel. Of course, CEOs and CFOs have been the key beneficiary of this trend.

From the mid-1990s to the early 2000s two independent surveys show that the share of stock options exercised in total corporate profit has steadily increased. For the Bureau of Economic Analysis they represented 12.4 per cent in 1997 and grew continuously until the 2000s, when they represented nearly 39 per cent of corporate profits. According to a survey by Business Week (2003: 38), option expenses as a percentage of net earnings of S\&P companies represented only 2 per cent in 1996, 8 per cent in 2000 and finally 23 per cent in 2003 (Table 5).

Nevertheless, a third and more problematic strategy has to be brought into the picture in order to explain the diverging evaluations in Figure 12: quoted corporations have intentionally inflated their profit statements, largely using the flexibility of Generally Accepted Accounting Principles (GAAP), playing the game of creative accounting and in some extreme cases using lies in order to bolster the rise in their share prices (Enron, Worldcom, Ahold). This is the unintended fall-out of the conjunction of shareholder value and the convention of a required return on equity (ROE) of 15 per cent. Such a target cannot be reached on a permanent basis by the majority of firms and sectors, so it is not really surprising if creative accounting has become one of the favourite disciplines taught in prestigious business schools and practised by CFOs. During this process CEOs, CFOs and top executives became rich, potentially or actually when they had the opportunity to exercise their stock options before the stock market nosedived. Again, this is further evidence of the discretionary power that benefits top management in modern corporations. 
EXTENSION OF DISCLOSURE RULES

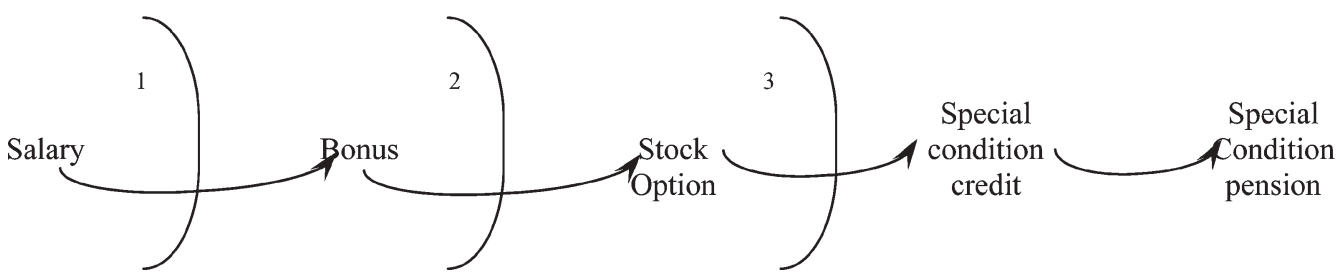

Fig. 13. From the transparent to the non apparent: the trickle down strategy of CEO about their compensation.

\section{A Last-resort Weapon of CEOs: the Shift from the Transparent to the Hidden}

Corporate misbehaviour is a recurrent pattern in the history of financial systems. Lawmakers then pass new Bills in order to prevent the repetition of financial scandals that are detrimental to the transparency required in order to foster and sustain the confidence of savers in the fairness of financial markets. The Sarbanes-Oxley legislation is no exception, but will it overcome the divergence in the interests of top executives and shareholders? Not necessarily, given the structural power exerted by CEOs at the corporate level. A brief retrospective analysis of the evolution of disclosure rules suggests a cautious approach to the issue of how managers are rewarded and controlled (Figure 13).

First the salaries of top management had to be made public, then disclosure was extended to bonuses and more recently to stock options, but none of it has prevented the use and abuse of this quite specific and not very efficient form of remuneration. The financial press has pointed out that even after implementing quite unsuccessful strategies some CEOs have left their corporations not only with golden parachutes but also with access to special personal credit facilities and, in some instances, special pension provision. Significantly, financial markets were oblivious to such conditions. This means that, even if legislation brings control over an extended share of CEO remuneration, such executives will still be able to devise new and innovative methods of gaining access to other and hidden (at least transitorily) forms of compensation.

\section{The Financialization of CEO Compensation: the Consequence of the Internal Restructuring} of the Divisions of the Quoted Corporation

The transformation of the structure of CEO compensation suggests another interpretation derived from the history of the internal organization of large American corporation. In the early days of the so-called American mass-production system stands the emblematic figure of an engineer who conceives new production methods and products: Henry Ford is a good example of such a view of the corporation. But the implementation of mass production triggered many problems with the work force (high turnover, strikes, absenteeism, poor product quality). Thus Personnel Management becomes an important division of the large corporation. During the inter-war period, one of the issues was the discrepancy between the explosion of mass production with a still limited market, due to an income distribution distorted in favour of the wealthiest stratum of the population. Such an imbalance meant that Marketing and Design became increasingly important corporate departments. 
Together these elements helped to deliver the configuration of the American corporation that emerged during the Golden Age of Sloanism.

But progressive financial liberalization triggered a series of innovations that called for the specialization of top management in financial asset management. Since the mid1980s the chief financial officer (CFO) has become a central figure in the American corporation. Whereas the expertise of the engineer, like that of the production system specialist, was largely specific to a sector, a product, a method of production or a certain type of equipment, financial management is much more homogeneous across corporations. Furthermore, in the era of global finance, the ability to generate financial profits by clever portfolio management has contributed to the performance of corporations that used to be focused on manufacturing and marketing. Last, but not least, the rise of the CFO fits quite well with the growing role of direct finance, since the $\mathrm{CFO}$ is in a good position to deal with institutional investors, analysts, trusts and pension funds and to convince them to buy shares in his/her company (Figure 14).

This shift in the distribution of power within quoted corporations may help explain at one and the same time the increasing share of stock options in the compensation of CEOs (Table 5) and the rapid increase in CEOs' total compensation: has the financial sector been the promoter of higher compensation (see Table 3)? If one believes in the cyclical pattern of managerial strategies and fads, the bursting of the Internet bubble and the rediscovery that mature sectors can provide a significant and stable rate of return could imply a comeback for the production manager, and by extension the R\&D manager, as the key competitive assets of the large corporation.

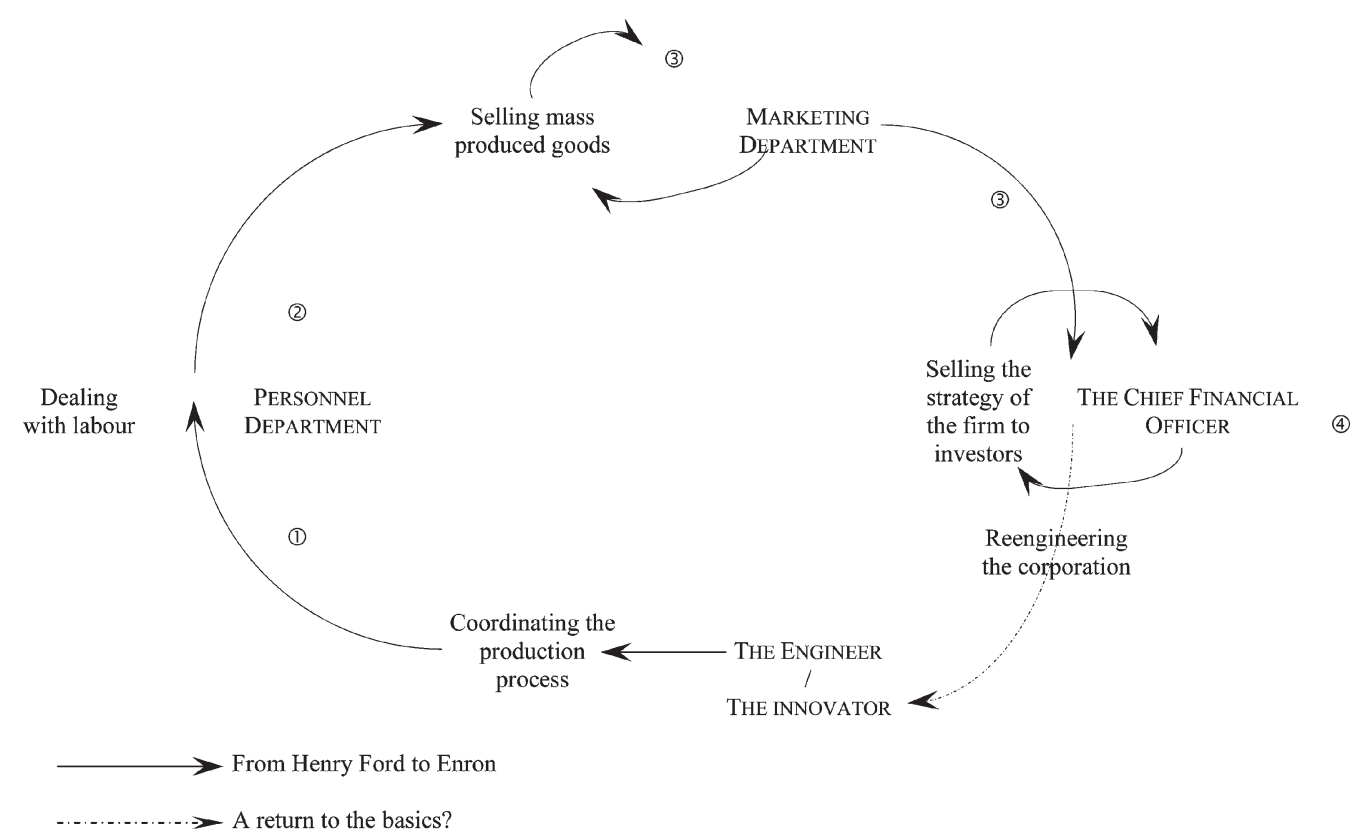

Fig. 14. The shift of internal control within the corporation: the rise of CFO as CEO. 


\section{The Power of Managers in the Political Arena}

It is now time to look beyond the inner micro-structure and functioning of the large corporation that give rise to the significant autonomy and power of top executives and explore how the insertion of the large quoted corporation into the social and political system has changed since the mid-1980s. The rise of CEO compensation and, in particular, the surge in stock options may find a series of relevant explanations at the macro-level.

\section{Financial Liberalization has been a Prerequisite for the CEO Compensation Explosion}

The internal shift in the hierarchy of the departments of the large firm shown by Figure 16 is closely related to the transformation in the American growth regime. Clearly, the explosion of CEO compensation and the rise of the CFOs could not have happened under the Fordist regime, since finance was strictly regulated and the major issue was about the mutual adjustment of production along with (largely domestic) demand, in accordance with the then overwhelming reference to the Keynesian style of monetary and budgetary policies. But the crisis of Fordism back in the late 1960s opens a period of major structural change, including import penetration, labour market deregulation, and financial innovation and liberalization. Wage earners' bargaining power is therefore eroded and, correspondingly, managers have to respond more to the demands of financial markets and less to those of labour. The reform of pensions plays a crucial role, since it links the evolution of the wage/labour nexus with the transformation of the financial regime (Montagne 2003). On one hand, the influx of pension funds into the stock market increases its liquidity and thus makes the market prone to financial bubbles. On the other, financial intermediaries and institutions put forward the idea that shareholder value should be the only concern of quoted corporations. The financialization and explosion of CEO compensation are the logical outcome of the interaction of these two mechanisms (Figure 15).

\section{When Economic Power is converted into Political Power}

This explanation in terms of political economy usefully complements a typically micro-grounded analysis of the power of managers within the corporation. It is an invitation to explore how they convert their economic power into the ability partially to shape economic policy according to their interests. Over the last two decades, large corporations have used both exit and voice in order to be influential in the political arena. First,

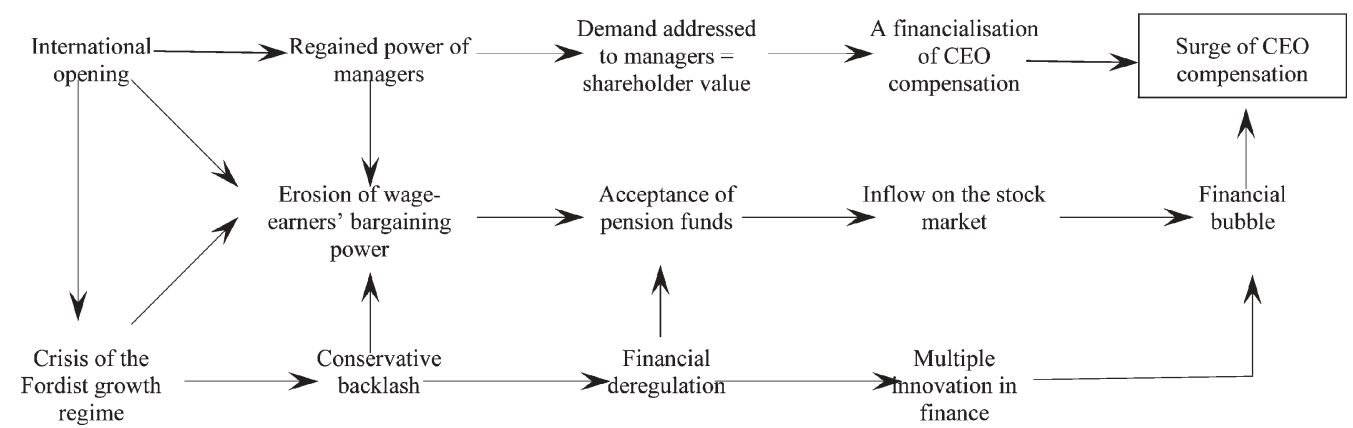

Fig. 15. The main episodes and factors in the financialisation of executive remuneration. 
with the great opening up of national economies and the free movement of capital, the managers of multinational corporations have been able to redraw domestic labour contracts according to the requirements of the competitiveness of their domestic sites of production (see Figure 5). Second, they have sought lower taxation of profits, on the implication that they might otherwise take up the preferential treatment on offer abroad. Thus managers have been combining the threat of delocalization, i.e. exit, along with voice via lobbying in the direction of lawmakers.

During the post-war Golden Age there was an implicit alliance between a fraction of the managers and wage earners, and this compromise was also embedded in the style of economic policy: the search for full employment, the constitution of welfare, as well as high and redistributive taxation. Nowadays, implicitly or explicitly, governments are adopting pro-business policies: deregulation of labour markets, slimming down of welfare benefits, lower taxation of high incomes, and an accommodating concept of fair competition. This is the context that has encouraged the profound transformation in the economic and social position of top managers. The purpose of the next section is to offer some evidence in order to sustain the hypothesis put forward by Figures 6 and 10: the transformation of core economic institutions during the last two decades has consolidated and legitimized the power of top managers at the society-wide level.

\section{The General Context of Rising Inequality}

In retrospect, it is clear that the period 1950-70 saw a quite unprecedented reduction of inequality. The top decile's income share (representing nearly 45 per cent in the 1930s) was

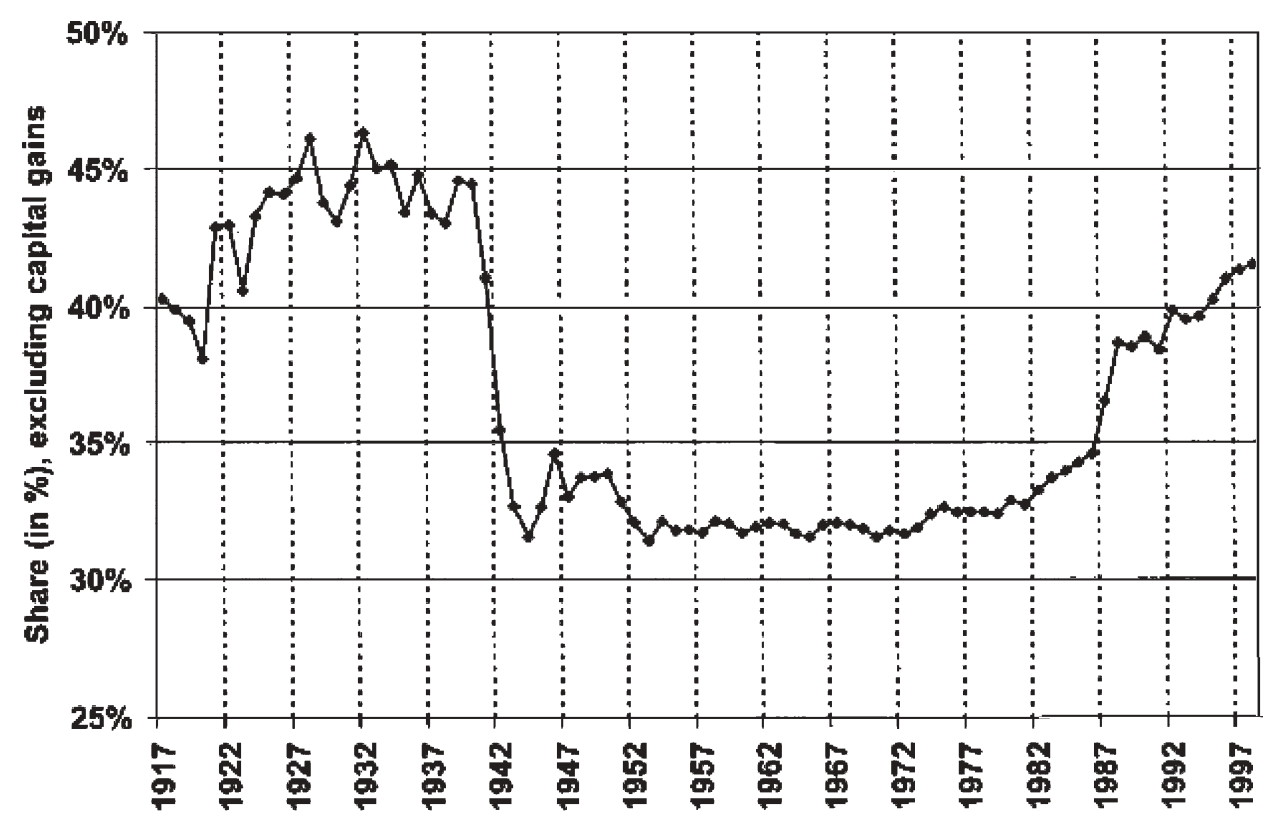

Source: Piketty, Saez (2003), figure 1, p. 11.

Reproduced with permission of MIT Press.

Fig. 16. The US: the top decile's income share, 1917-1998. 
drastically reduced to 32 per cent after the Second World War. This proportion rose slowly from 1973 to 1987, before rising rapidly during the 1990s (Figure 16). This upward trend coincided first with the stiffening of foreign competition and labour market deregulation (1973-87) and then with the evolution of the American economy towards a finance-led regime (1988-97).

This rising inequality within households assumed a specific form in the United States, where the redistributive role of taxation (see Tables 6-7) and a limited universal welfare could not counteract the trends generated by labour markets. For nearly three decades more precisely, from 1971 to 1995 - the poorest 20 per cent of households experienced near stagnation of their real income after taxation. By contrast, the most affluent households became still more affluent, especially after 1987 and after 1995 (Figure 17). These shifts coincide with the dates of international pressure on American competitiveness (the mid1980s) and the boom in financialization (1995).

The compensation of CEOs has been evolving within this general context. In the United States, over the last two decades, attitudes to the dividing line between legitimate and exorbitant inequality have been shifting. The question is then: how have capital and entrepreneurial incomes contributed to such a rise in the income of the richest 1 per cent of the population?

The Surge of Entrepreneurial Incomes contributes to the Growing Number of Super-rich A recent study compares the distribution of total income between wages, capital income and entrepreneurial income among the wealthiest 10 per cent of the population at two periods, in

\section{TABLE 6}

Contrasted evolutions of US tax rates for middle-class and wealthy families

\begin{tabular}{lll}
\hline Year & \multicolumn{2}{l}{ Effective federal tax rate } \\
\cline { 2 - 3 } & Median family & Millionaire or top 1\% \\
\hline 1948 & 5.30 & 76.9 \\
1955 & 9.60 & 85.5 \\
1960 & 12.35 & 66.9 \\
1965 & 11.35 & 68.6 \\
1970 & 16.06 & \\
1975 & 20.03 & 35.5 \\
1977 & & 31.7 \\
1980 & 23.68 & \\
1981 & 25.09 & \\
1982 & 24.46 & \\
1983 & 23.76 & \\
1984 & 24.25 & 24.9 \\
1985 & 24.44 & \\
1986 & 24.77 & 26.9 \\
1987 & 23.21 & \\
1988 & 24.30 & \\
1989 & 24.37 & \\
1990 & 24.63 & \\
\hline
\end{tabular}

Source: Phillips (2002: 96). 
TABLE 7

The declining share of the US federal tax burden paid by corporations and the rising share of payroll taxes

\begin{tabular}{llc}
\hline Year & \multicolumn{2}{l}{ Share of total receipts $(\%)$} \\
\cline { 2 - 3 } & Corporate taxes & Payroll taxes $^{a}$ \\
\hline 1950 & 26.5 & 6.9 \\
1960 & 23.2 & 11.8 \\
1970 & 17.0 & 18.2 \\
1980 & 12.5 & 24.5 \\
1990 & 9.1 & 35.5 \\
2000 & 10.2 & 31.1 \\
\hline
\end{tabular}

Note:

a Social security and Medicare

Source: Phillips (2002: 149).

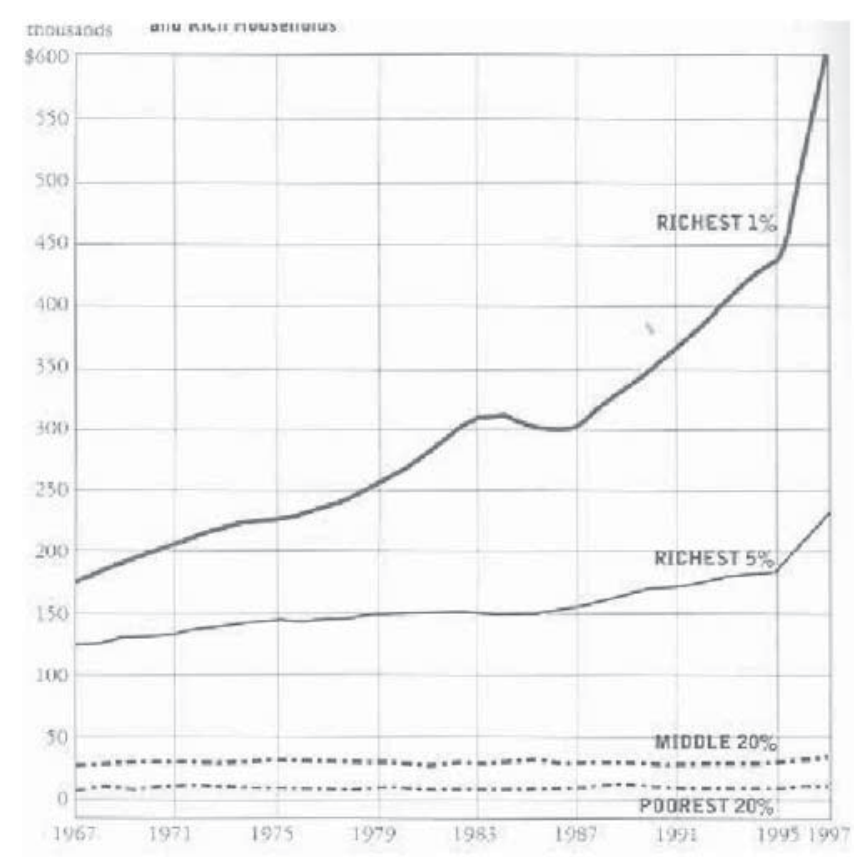

Source: Phillips, K. (2002), p.128.

Fig. 17. The polarisation of America (1967-1997). Average inflation-adjusted annual after tax income of poor, middle class, and rich households.

1998 and 1929 (Piketty \& Saez 2003). Whereas in 1929 capital income represented 70 per cent of the income of the wealthiest 1 per cent of households, in 1998 this source of income represented only 10 per cent, since the largest proportion of income is related to wages. Nevertheless, a quite interesting feature is that the share of entrepreneurial income is 
Panel A: 1929

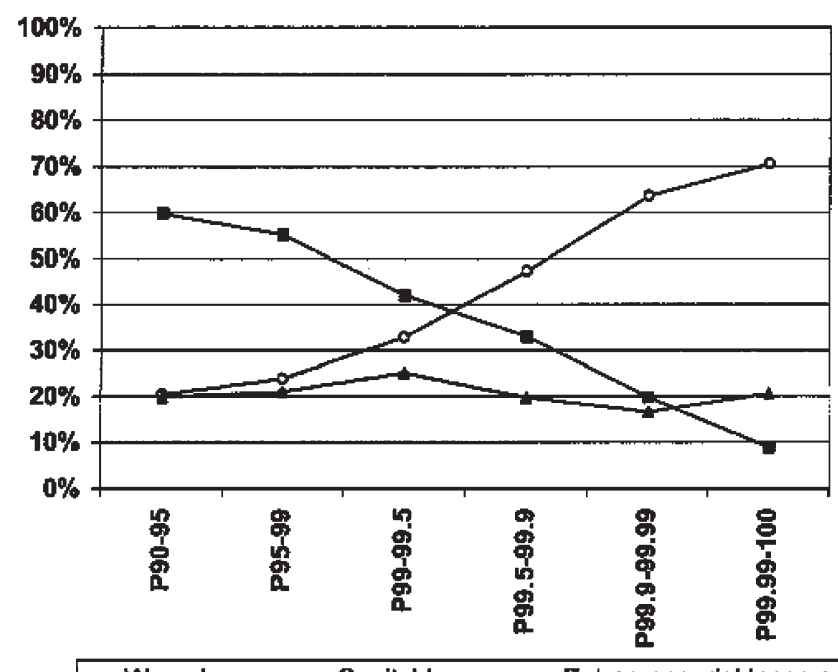

- Wage Income -o-Capital Income - Entrepreneurial Income

Panel B: 1998

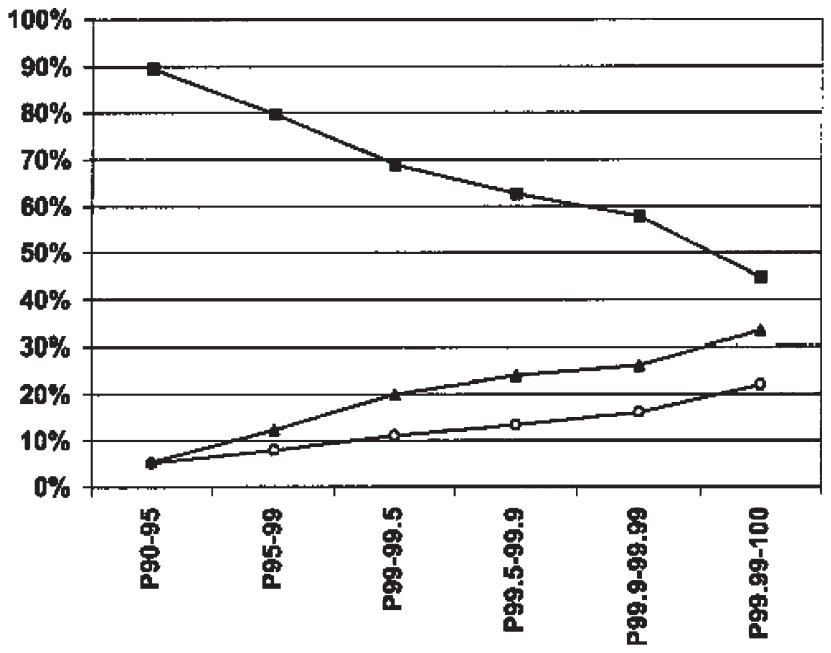

-Wage Income -o-Capital Income +-Entrepreneurial Income

Source: Piketty and Saez (2003), figure 4, p. 16.

Reproduced with permission of MIT Press.

Fig. 18. The US: Income composition of top groups within the top deciles in 1929 and 1998.

increasing steadily as we shift from the wealthiest 5 per cent to the wealthiest 1 per cent (Figure 18). Interestingly, the share of capital income is also increasing, but at most it represents 20 per cent of total income for the wealthiest 1 per cent. In comparison with the inter-war period, these data suggest two conclusions: 


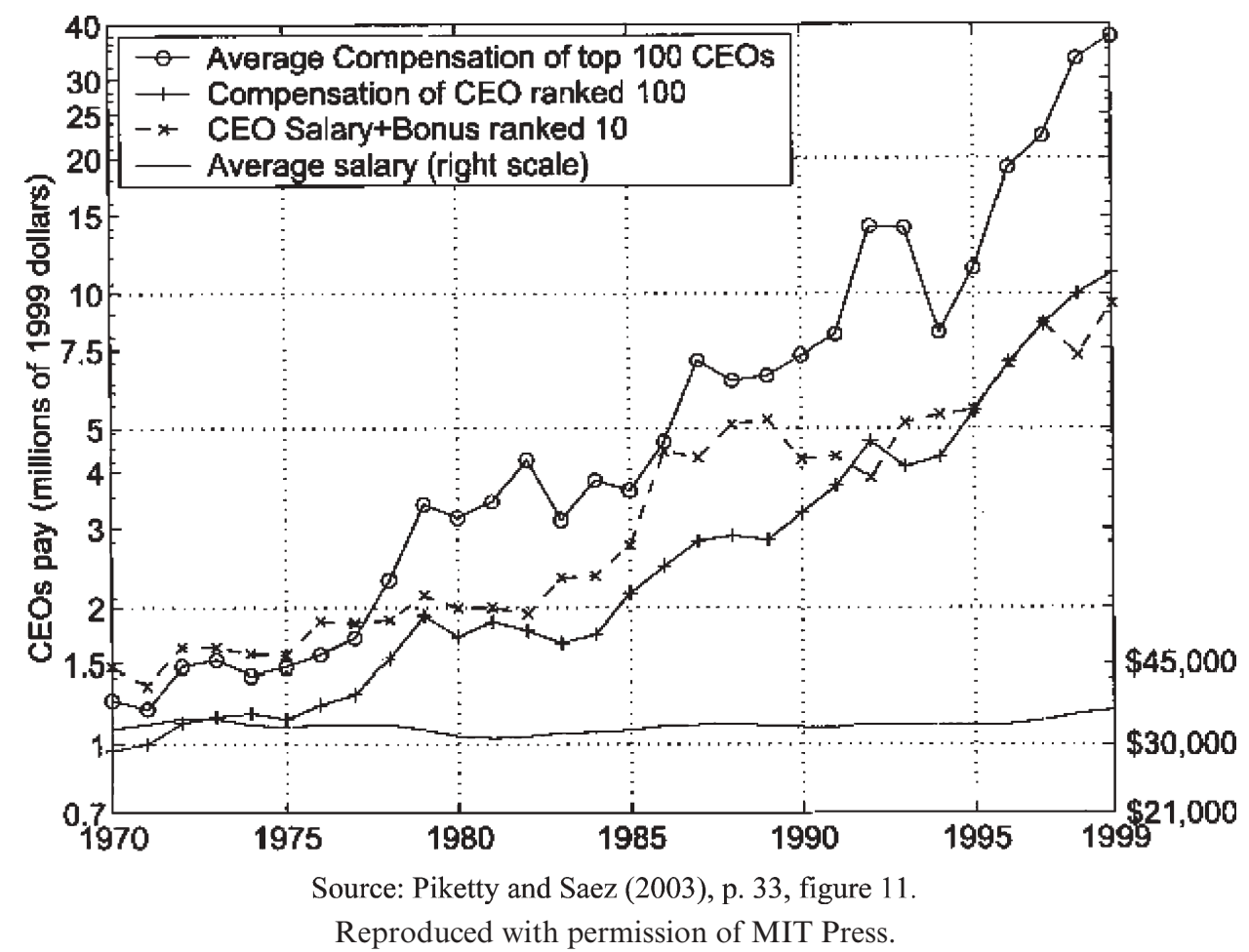

Fig. 19. The US: CEO pay versus average wage, 1970-1999.

1 First, the wealthiest part of the population nowadays belong to the elite of wage earners and they combine the two other sources of income, which complement rather than substitute for wages.

2 Second, the fact that income of entrepreneurial origin is increasing among the top percentiles faster than income derived from capital suggests that the power of managers has been more significant than the power of financiers.

\section{Top Executives have Divorced from Labour}

More direct evidence of the power of CEOs can be found in the same research (Figure 19). Back in the early 1970s, the average compensation of the top ten CEOs was around $\$ 1.3$ million (at 1999 prices), whereas the average salary was around $\$ 40,000$. Since 1975 the trends of these two variables have been diverging: over a quarter of a century there has been quasi-stagnation of the average salary, while rapid and quasi-continuous increases in the average compensation of the top 100 CEOs allowed pay to reach the level of $\$ 40$ million in 1999. Again, an acceleration of CEO total compensation after 1995, i.e. the beginning of the financial bubble in the United States, can be noted.

These figures seem to confirm the core hypothesis of this article: benefiting from the competitive threat exerted by foreign competition, and even more so as a consequence of corporate governance of financialization, American CEOs no longer consider themselves as the elite of the permanent wage earners. Nevertheless, in Gemany or Japan CEOs continue to see themselves as the upper stratum of wage earners. Not any more in the United States, where they are part of an implicit alliance with financiers. 


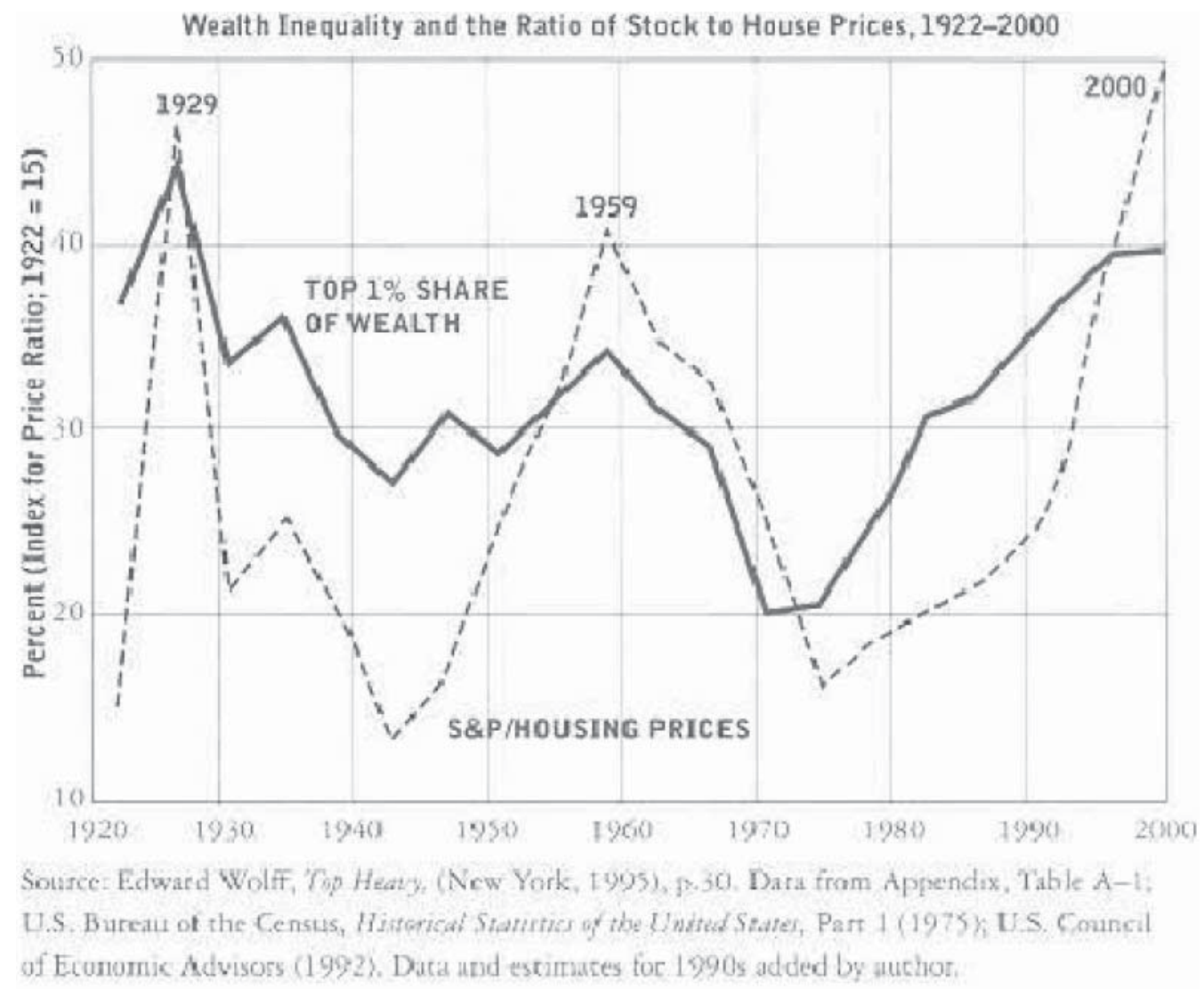

Source: Phillips, K. (2002), p. 79.

Fig. 20. The US wealth inequality and stock market peaks.

\section{The Concentration of Wealth goes along with Stock Market Bubbles}

In historical retrospect, the surge of inequality in terms of income, and even more so wealth, is closely associated with the waves of financial speculation, at least in economies such as that of the United States, where tax and welfare systems do not have significant redistributive effects (Figure 20). The previous developments suggest that top executives benefit more than the typical rentier, even though finance seems to play the leading role in shaping the objectives and organization of the corporate world. If financial markets constrain corporate strategies in the short run by their rapid changes in the value of stocks, in the long run executives of service and manufacturing firms do control the sources of profit.

\section{The Tax System is Redesigned in Favour of the Wealthiest}

In European countries, such a pattern is less marked and can be mitigated by intensive redistribution via progressive income tax, heavy inheritance tax and of course the role of universal welfare. Such is not the case in the United States, since rich individuals do participate in political debates and polls. Consequently, they are more efficient at 
lobbying in order to deliver reductions in the high-bracket income marginal tax than the underprivileged are at mobilizing in favour of redistributive measures.

Whereas the effective federal tax rate for the median American family has been nearly constant since 1980, after a significant increase since the 1960s, the shift has been in the opposite direction for millionaires and the top 1 per cent wealthiest households (Table 6). Similarly, corporate taxes have been declining to very modest levels (10 per cent), but payroll tax and welfare contributions are at 31 per cent in 2000, up from 6.9 per cent in 1950 (Table 7). This is new evidence in favour of a political economy interpretation that links the political and economic spheres.

Considering all the previous evidence, it becomes clear that the power of managers is not restricted to the information and power asymmetry typical of any firm, and which is exacerbated in the large corporation. At the society-wide level, the rise of entrepreneurial income, the evolution of the conception of social justice (market allocations are fair), the revision of income tax, and finally the reduction in the share of corporations in total tax receipts confirm the hypothesis of a renewed political power on the part of large corporations, and especially of their top executives.

\section{Conclusion: Managers, Financiers and Politicians}

The main objective of this article has been to propose an explanation for one of the biggest contemporary paradoxes, i.e. the explosion of CEOs' compensation far ahead and frequently quite independently of the actual performance of their corporations.

\section{The Contemporary Situation in Historical Perspective}

The issue of the control and reward of managers is an integral part of the wider question about the nature of corporate governance in a world of largely open national economies and global finance. Contemporary concerns about the legitimacy and efficacy of stock option grants as an incentive for controlling managers have their origins in the crisis of the Sloanist corporation and the related domestic growth regime. The progressive opening-up to world competition, labour market deregulation and then financial deregulation, the rise of pension funds and the evolution of the bargaining power of unions have induced a dual shift. At the company level, restructuring has affected production organization but also shifted priorities to financial management. At the macroeconomic level, the previous model based on mass production and consumption has undergone a crisis, and after a long period of trials and errors the engine of growth has been the outcome of the synergy between financial innovations and the creation and diffusion of information and communication technologies.

\section{The Plea for Stock Options has no Theoretical Rationale}

The arguments that have been used to justify the introduction of preferred stocks or stock options have proven to be erroneous by contemporary theories as well as by many empirical evidences. The interests of professional managers and owners can never be fully reconciled, and the diffusion of ownership makes the control of managers still more difficult. Incidentally, optimal contract theory would advise the use of indexed stock options, that would 
reward only relative performance with respect to peers, filtering out the perverse effects associated with past dependence, lax monetary policy, macroeconomic and sectoral booms and last but not least the macro-inefficiency of financial markets. The fact that only a minority of stock options are indexed means that they are not at all endorsed by contemporary micro-analyses of principal/agent literature and the theory of contracts. The idea that stock options were the required complements to shareholder value and value creation has been invalidated by the evolution of the rate of return on equity of large corporations during the 1990s. Almost no empirical study finds a positive correlation between option grants and the economic performance of the firm. Repeated financial scandals have made clear the difference in the interests of and the returns for top managers and the average stockholders respectively.

\section{The Intrinsic Power of Managers at the Firm Level and its Extension at the Society-wide Level}

The observed asymmetry between top managers and stockholders finds its origins at the core of the objective of the firm: how to generate profits? The old conventional neoclassical theory states that profit results from the optimal combination of totally substitutable factors of production: labour, equipment and managerial talents, in response to their market prices. On the contrary, modern theorizing on the firm stresses that a positive net profit is the outcome of the combination of complementary assets and firm-specific competences: none of these factors can be bought or mimicked by the market, still less by financial markets. Who is in charge of generating these profits? Precisely, the top executives. The very reason that makes the firm efficient confers on CEOs and CFOs significant economic power. First, they have access to the relevant and private information that has not necessarily to be made public (for instance, about the real sources - and even the amount of profit generated by the firm). Second, they have a better knowledge than shareholders, analysts or fund managers of the strengths and weaknesses of the firm, since they know the routines and the synergies that make the firm profitable. (Outsiders are best equipped to analyse the impact of macroeconomic/sectoral variables upon the evolution of the profit, not its internal determinants.) Third, CEOs and directors have the power to make decisions about the strategy as well as the day-to-day management of the firm. (Shareholders have only ex post control, mainly by exit, i.e. selling their shares, and annually they have a chance to voice their opinion and cast their vote on an agenda set by the corporation.) Managers' control over their remuneration largely results from this intrinsic asymmetry. In the era of financialization this superiority took the form of remuneration by stock options. In the past it had another form (salaries, bonuses), and in the future it will evolve toward new forms.

In the 1990s, in defence of shareholders, managers have converted this internal power into financial wealth, thus benefiting from the liquidity and the speculative bubble associated with the Internet. Given the long-lasting erosion of wage earners' bargaining power and the shift of governments towards a pro-business stance, the business community has lobbied for reform of labour laws and the welfare and the tax systems. In a sense, the economic power of managers has been extended to include a significant dose of political power. For instance, the fact that stock options enjoyed privileged taxation status, and were not regarded as a cost to be taken into account in the evaluation of profits, created a virtuous circle of seemingly impressive company performance and the rise of stock market valuations. 
This is why the optimal contract approach to the control and rewarding of managers is bound to fail, given the intrinsic power of top managers, the origin of which is related to the very sources of profit in contemporary capitalism. By contrast, combining a managerial power approach with a typical political economy analysis conveys a simple and rather convincing interpretation of the paradox under review. Under the motto of shareholder value, managers implicitly allied with financiers in order to extend their power and remuneration.

\section{The Search for a New Form of Corporation?}

The limits of the current organization of quoted corporations have become clear since the early 2000s, and almost all countries are trying to cope with the issue of managerial control. This article has argued that there is no panacea but it has pointed to two possible items on the agenda of corporate reform. First, any move from a purely shareholder vision towards $a$ stakeholder conception of the corporation would reduce the probability of managerial greed and erroneous strategic decisions. Second, no contract is self-enforcing and therefore some other form of public control of the accounting practices of quoted corporations is required in order to prevent an alliance between CEOs and auditors, at the expense of rank-and-file shareholders. Lastly, some macroeconomic contexts are more likely to generate speculative bubbles and allow excessive power to CEOs: when inflation and consequently interest rates are low, de facto the central bankers may be at the origin of financial speculation, and indirectly trigger quite detrimental strategies on the part of top executives. During the 1980s in Japan and subsequently during the 1990s in the US, monetary policy has been at the heart of erroneous business strategies and unjustified wealth from CEOs. All policy makers should learn from this episode.

\section{Acknowledgement}

This article develops the ideas presented at the conference on 'Controlling and Rewarding Managers' held at the University of Manchester, 14 May 2004.

\section{Note}

1 For instance, Chauvin and Shenoy (2001) show that on average stock prices usually decrease prior to executive stock options grants.

\section{References}

Aglietta, M. (1982) Regulation and Crisis of Capitalism (New York, Monthly Review Press).

Bebchuk, Lucian A. (2004) The Case for Shareholder Access: A Response to the Business Roundtable', SEC round table, 10 March.

Bebchuk, Lucian A., \& Fried, Jesse M. (2003) Executive compensation as an agency problem, Journal of Economic Perspectives 17 (3), pp. 71-92.

Berle, A., \& Means, G. (1932) The Modern Corporation and Private Property (2nd edn 1991, New Brunswick NJ, Transaction Publishers).

Biondi, Y., Bignon, V., \& Ragot, X. (2004) Une analyse économique de l'évolution des normes comptables européennes: le principe de «juste valeur» (mimeo), Centre de recherche en économie Saint-Gobain, 24 March. 
Boyer, R. (2000) Is a finance-led growth regime a viable alternative to Fordism? A preliminary analysis, Economy and Society 29 (1), pp. 111-45.

Boyer, R. (2004) The Future of Economic Growth as New becomes Old (Cheltenham, Elgar).

Boyer, R., \& Freyssenet, M. (2002) The Productive Models (Chippenham, Palgrave Gerpisa).

Boyer, R., \& Juillard, M. (2002) The United States: goodbye, Fordism! in R. Boyer \& Y. Saillard (eds) Régulation Theory. The State of the Art (London, Routledge), pp. 238-56.

Business Week (2003) Beyond options, European edn, 28July, pp. 38-9.

Business Week (2004a) The best and the worst managers of the year, European edn, 12 January pp. 35-63.

Business Week (2004b) Corporate governance: investors fight back, special report, European edn, 17 May, pp. 53-67.

Chauvin Keith, W., \& Shenoy, C. (2001) Stock price decreases prior to executive stock option grants, Journal of Corporate Finance 7 (1), pp. 53-76.

Conyon, Martin J., \& Murphy, Kevin J. (2000) The prince and the pauper? CEO pay in the United States and United Kingdom, Economic Journal 110 (November), F640-71.

Economist (2003) Executive pay: fat cats feeding, 9 October, p. 37.

Erturk, I., Froud, J., Johal, S., \& Williams, K. (2005) Pay for corporate performance or pay as social division? Rethinking the problem of top management pay in giant corporations, Competition \& Change 9 (1) pp. 49-74.

Fidrmuc, Jana P., Goergen, M., \& Renneboog, M. (2003) Directors' Share Dealing and Corporate Control (mimeo), University of Manchester.

Himmelberg, Charles P., \& Mahoney, James M. (2004) Recent revisions to corporate profits: what we know and when we knew it, Federal Reserve Bank of New York 10 (3).

Jensen, M., \& Meckling, W. (1976) Theory of the firm: managerial behavior, agency costs and ownership structure, Journal of Financial Economics 3, pp. 305-60.

Jensen, M., \& Murphy, K. (1990) Performance pay and top-management incentives, Journal of Political Economy 98 (2), pp. 225-64.

Johnson, J. (2003) US: CEO pay continued upward spiral in 2002, www.wsws.org/articles/2003/ceoj03_prn.shtml.

Kaplan, Steven N., ed. (2000) Mergers and Productivity, NBER Conference Report series (Chicago and London, University of Chicago Press).

Lazonick, W. (1992) Controlling the market for corporate control: the historical significance of managerial capitalism, Industrial and Corporate Change 1 (3), pp. 445-88.

Lordon, F. (2002) La Politique du capital (Paris, Odile Jacob).

Main, Brian C., O'Reilly III, Charles A., \& Wade, J. (1995) The CEO, the board of directors and executive compensation: economic and psychological perspective, Industrial and Corporate Change 4 (2), pp. 293-332.

Montagne, S. (2003) Les Métamorphoses du trust: les fonds de pension américains entre protection et spéculation (thesis, University of Paris 10 - Nanterre).

Murphy, Kevin J. (1999) Executive compensation, in C. Orley \& David C. Ashenfelter (eds), Handbook of Labor Economics IIIb, pp. 2485-563.

Orléan, A. (1999) Le Pouvoir de la finance (Paris, Odile Jacob).

Phillips, K. (2002) Wealth and Democracy (New York, Broadway Books).

Piketty, T., \& Saez, E. (2003) Income inequality in the United States, 1913-1998, Quarterly Journal of Economics, February, pp. 1-39.

PIRC (Pensions \& Investment Research Consultants Ltd) (2003) Directors' Remuneration: Evidence to the Trade and Industry Committee (mimeo), London, PIRC.

Stathopoulos, K., Espenlaub, S., \& Walker, M. (2005) The compensation of UK executive directors: lots of carrots but are there any sticks? Competition \& Change, 9 (1), pp. 89-106.

Temin, P. (1999) The stability of the American business elite, Industrial and Corporate Change 8, pp. 189-209.

Yermack, (1997) Good timing: CEO stock option awards and company news announcements, Journal of Finance, June, 52, 449-76. 


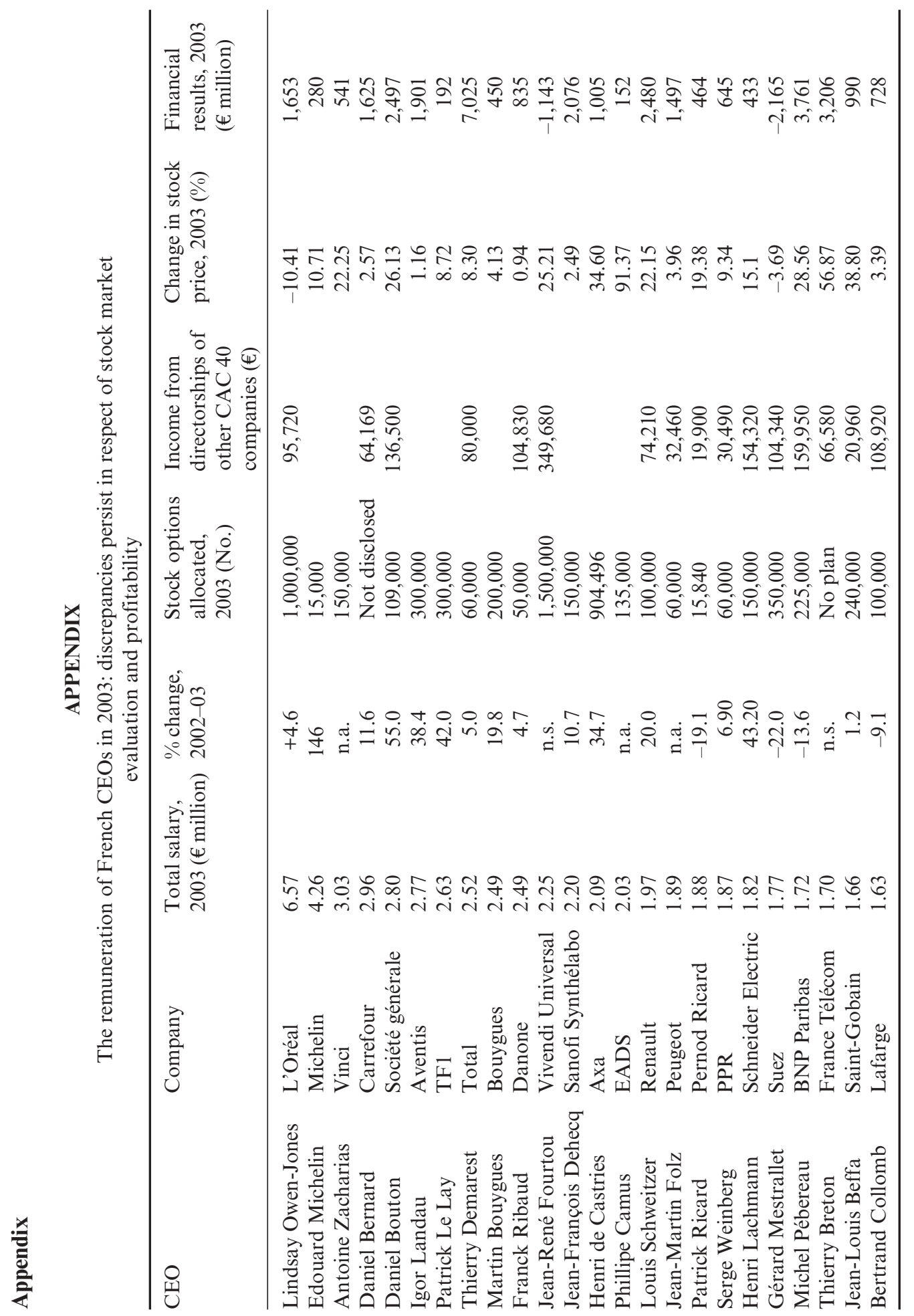






